\title{
Predicting Firm Level Stock Returns: Implications for Asset Pricing and Economic Links
}

\author{
David G McMillan \\ Division of Accounting and Finance \\ University of Stirling \\ September 2017 \\ Revised April 2018 \\ Second Revision November 2018 \\ This Version March 2019
}

\begin{abstract}
We examine the predictive ability of stock price ratios, stock return dispersion and distribution measures for firm level returns. Analysis typically focusses on market level returns, however, for the underlying asset pricing model to hold, firm-level predictability should be present. Additionally, we examine the economic content of predictability by considering whether the predictive coefficient has the theoretically correct sign and whether it is related to future output growth. While stock returns reflect investor expectations regarding future economic conditions, they are often too noisy to act as predictor. We use the time-varying predictive coefficient as it reflects investor confidence in the predictive relation. Results suggest that a subset of stock price ratios have predictive power for individual firm stock returns, exhibit the correct coefficient sign and has predictive power for output growth. Each of these ratios has a measure of fundamentals divided by the stock price and has a positive relation with stock returns and output growth. This implies that as investors expect future economic conditions to improve and earnings and dividends to rise, so expected stock returns will increase. This supports the cash flow channel as the avenue through which stock return predictability arises.
\end{abstract}

Keywords: Stock Returns, Predictability, Firm-Level, Asset Pricing, Output JEL Codes: C22, G12

Address for Correspondence: Professor David McMillan, Accounting and Finance Division, University of Stirling, FK9 4LA, Scotland, UK

Phone: +44(0)1786-467309; Fax: +44(0)1786-467308

e-mail: david.mcmillan@stir.ac.uk 


\section{Introduction.}

An increasing amount of literature examines the predictability of stock returns and argues that valuation ratios have predictive power. Most prominent among these include the dividend-price ratio, the price-earnings ratio and the latter's cyclically adjusted version. Other ratios utilised often include the dividend payout ratio and the Fed model. More recently, measures of dispersion are considered and reported as successful in providing predictive power. ${ }^{1}$

The vast majority of this work focuses on predicting market level stock return behaviour. This paper deviates from that approach by considering panel regression model based evidence for individual stocks across ten international stock markets. Thus, one aim of this paper is to examine whether the predictor variables often reported at the market level also hold at the firm-level. This is important as our understanding of asset pricing must ultimately to be able to explain movements in firm-level valuation. Moreover, as expressed by Jung and Shiller (2005), we would expect firm-level stock prices to have a closer link with fundamentals compared to market level index values. Thus, greater evidence of predictive power should be found at the firm-level if the identified predictor variables act as good proxies for fundamental information.

An overriding concern within the predictability literature is whether the existence of any predictive power has a wider economic meaning. The movement of stock market returns is a window on to future economic behaviour as it represents investor expectations of future economic conditions. Thus, movement in current stock returns reflects changes in investor views of future cash flow and risk as their expectations of future economic performance changes. This implies two important elements that we would expect to find with respect to the nature of the predictive regression. First, the estimated coefficients should be consistent with

\footnotetext{
${ }^{1}$ See, for example, Campbell and Shiller (1988), Lewellen (2004), Kellard et al (2010), Cochrane (2011), Maio (2013, 2016) and McMillan (2014a, 2015).
} 
any economic interpretation that is afforded them. Second, the estimated coefficients should be related to future movements in economic behaviour. For example, a strengthening of the predictive relation would imply greater confidence in the information concerning future economic conditions that arises from movements in the predictor variable.

Therefore, a further aim of this paper is to conduct time-varying rolling regressions and to analyse the behaviour of the predictive coefficients and whether they are related to future output growth. Of note, while there exists a raft of research that links movements in output to future stock returns (see, for example, Rangvid, 2006; Cooper and Priestley, 2009, 2013), there is less evidence showing the predictive power of stock returns on output growth (examples include, Mauro, 2003; Henry et al, 2004). Evidence of such a relation would support linkages between stock market dynamics and the macroeconomy consistent with those implied within asset pricing models.

This paper thus contributes to our understanding of financial markets and the links with the macroeconomy is several ways. Asset pricing models argue that movement in stock returns are linked to expectations regarding subsequent movements in cash flows and risk premium. Hence, support for key asset pricing models can be found through evidence of predictability arising from variables that can proxy for cash flow and risk. Crucially, we not only consider whether there is support for predictability but also whether the sign of the predictive coefficient has economic meaning. Moreover, additional supportive evidence for asset pricing models is considered by linking the predictive relations with subsequent movements in output growth. This further enhances our understanding of the links between financial markets and the macreoconomy. Current evidence focuses on market level stock return data, so this paper adds to the weight of evidence by considering firm-level data. To date, the majority of work that considers firm-level data see, for example, Bulkley and Taylor (1996), Vuolteenaho (2002) and Nasseh and Strauss (2004) for the US and Goddard et al (2008) for the UK, test the present 
value model, the existence of a long-run relation between stock price and dividends and the drivers of stock returns. This work does not explicitly consider predictive regressions in the manner examined here. Laopodis (2016) for the US and McMillan (2010) for the UK consider predictability at the sector or industry level. Thus, this paper extends the existing work by considering firm-level predictability across a range of countries and predictor variables.

The results of this paper, which consider stock return predictability and its links to the wider economy will, in turn, further inform the debate regarding the cash flow and risk channels of asset price movement (see, for example, Cochrane, 2011; Ang, 2011; Rangvid et al, 2014). This is key in our understanding of the drivers of asset price movement and will be of interest to academics involved in asset pricing research both at a theoretical and empirical level and investors who wish to know the factors that govern stock price movement.

\section{A Brief Literature Review on Stock Return Predictability.}

As noted in the Introduction, the majority of research in this area focuses on market level stock index behaviour. The literature using financial ratios to predict stock returns largely began with Campbell and Shiller (1988) and Fama and French (1988) who consider dividend- and earnings-price ratios. Subsequent research (e.g., Lamont, 1998; Ang and Bekaert, 2007; Campbell and Thompson, 2008; Kellard et al, 2010; Maio, 2013) considers these and related ratios with mixed evidence on predictive success. The majority of the research in this area limits the analysis either in terms of the market examined or the explanatory variables considered and typically focuses on the US and the dividend- (or earnings-) price ratio. In contrast, Welch and Goyal (2008) consider a wider range of explanatory variables for the US and report limited evidence of predictability. Hammerschmid and Lohre (2018) likewise consider a range of explanatory variables for the US market but argue in favour of greater predictability when allowing for macroeconomic regimes of behaviour. Hjalmarsson (2010) 
considers a range of markets (with fewer explanatory variables) and again reports only limited supportive evidence. Moreover, both Welch and Goyal and Hjalmarsson specifically argue that financial ratios are poor predictors

In considering the mixed nature of the predictability results, several papers argue that the predictive relation is characterised by time-variation. This variation could arise in the predictor variables (Lettau and van Nieuwerburgh, 2008) or the predictive coefficient (Paye and Timmermann, 2006). Others argue that evidence for the presence of predictability arises only in short time periods (Timmermann, 2008), switches with periods of dividend growth predictability (Chen, 2009, McMillan and Wohar, 2013) or varies with the economic cycle (Henkel et al, 2011; Hammerschmid and Lohre, 2018). Beyond this, several researchers specify explicit non-linear models that may be related to the state of the market or wider economy (see, for example, McMillan, 2003; Psaradakis et al, 2004; McMillan and Wohar, 2010).

The above cited work considers the ability to predict market-level stock returns. In respect of more disaggregated data, existing work typically considers the nature of the relation between prices and dividends (or earnings) and the implications for the present value model rather than stock return predictability itself. Notably, Bulkley and Taylor (1996) argue that firm-level US stock prices do not follow the present value model, while Nasseh and Strauss (2004), also examining individual stocks for the US, argue the present value model relation broke down in the 1990s. Goddard et al (2008) conduct a similar exercise for individual UK firms and report more supportive evidence for the present value model. In a different tact, Vuolteenaho (2002) uses the underlying present value model description to identify the drivers of firm-level stock returns and argues that cash flow news plays a larger role. This contrasts with the market level arguments of Cochrane (2011), where movements in the risk premium (expected returns) play a dominant role. In terms of stock return predictability itself, McMillan (2010) for the UK and Laopodis (2018) for the US examine the ability of financial ratios and 
a small set of macroeconomic data to achieve this. However, this work takes place at the sector level rather than the individual stock level.

Aside from financial ratios, Maio (2016) considers the use of stock return dispersion for stock return predictability. Maio uses style portfolios (size and value) and considers whether the cross-section standard deviation predicts the market-level return. Maio argues that this measure does indeed outperform financial ratios and a selection of other predictors. Although not in the predictive regression setting, Amaya et al (2015) consider whether skewness can explain the cross-sectional behaviour of US stocks. They argue that portfolios constructed according to the degree of stock return skewness can lead to improved performance.

This paper, therefore, seeks to bring together and the expand upon the several strands of the above lineage of research. The existing predictive regression research considers market (e.g., Welch and Goyal, 2008) and sector (e.g., McMillan, 2010) level data, which we extend by firm-level data. In turn, existing firm-level research (e.g., Nasseh and Strauss, 2004) focusses on the relation between stocks and dividends, which we extend by considering predictive regressions. We utilise predictive variable across financial ratios (e.g., Campbell and Shiller, 1988), measures of dispersion (e.g., Maio, 2016) and additionally consider the distribution. In examining the predictive regressions, we consider both variation across time (e.g., McMillan and Wohar, 2013) but also across firms. Furthermore, we link the predictive regressions to measures of output and thus seek to provide further evidence on the main driver of stock market return movements (e.g., Vuolteenaho, 2002).

\section{Theoretical Motivation.}

The present value, dividend discount model (Campbell and Shiller, 1988) forms the underlying approach that motivates both the predictability regression and the links between stock returns and macroeconomic variables more widely. The fundamental stock price is given by: 


$$
P_{t}=\sum_{i=1}^{\infty} \delta^{i} E_{t} D_{t+i}
$$

where $P_{t}$ and $D_{t}$ represent prices and dividends, $\delta=1 /(1+R)$ is the discount factor and $R$ the discount rate. $\log$ returns are given by $r_{t} \equiv \log \left(P_{t}+D_{t}\right)-\log \left(P_{t-1}\right)$, with the time-varying $\log$ return a non-linear function of $\log$ prices and dividends. Using an approximation around a firstorder Taylor expansion equation (1) becomes:

$$
p_{t}=k+E_{t}\left(\sum_{i=0}^{\infty} \rho^{i}(1-\rho) d_{t+i+1}\right)+E_{t}\left(\sum_{i=0}^{\infty} \rho^{i} r_{t+i+1}\right)
$$

where $k$ is a linearisation parameter and $\rho$ a constant discount factor. Imposing the transversality condition, which rules out explosive behaviour in order to only consider fundamental information, equation (2), in terms of the log price-dividend ratio, is given by:

$$
p_{t}-d_{t}=(k / 1-\rho)+E_{t} \sum_{i=0}^{\infty} \rho^{i}\left(\Delta d_{t+i+1}-r_{t+i+1}\right) .
$$

Intuitively, this relation states, that if dividends are expected to grow or the future discount rate is expected to be low (or some combination of both), then current prices will be higher, and the price-dividend ratio will be high. More generally, following equation (3), Lamont (1998) shows that the time $t$ expectation of time $t+1$ returns can be written as:

$$
E_{t}\left(r_{t+1}\right)=-p_{t}+E_{t}\left(\sum_{i=0}^{\infty} \rho^{i}(1-\rho) d_{t+i+1}\right)+E_{t}\left(\sum_{i=0}^{\infty} \rho^{i} r_{t+i+1}\right)+k
$$

Again, this equation shows the relation between stock returns and future dividends (more generally, cash flow) and returns (risk premium). Moreover, this implies that after controlling for the time $t$ stock price, any variable known at time $t$ can only predict returns at time $t+1$ if it proxies for expected future discounted cash flow or expected future returns.

Furthermore, this model motivates our key research interests within the paper. First, equation (4) indicates that expected stock returns should contain predictive power for future macroeconomic conditions. An improving future economic outlook will lead to higher 
expected dividends and lower expected risk, which in turn are related with stock returns. Moreover, the sign of the relation between expected stock returns and output differs depending on whether the cash flow or risk channel dominates. Specifically, while higher dividends and risk both exhibit a positive relation with stock returns, they operate over different phases of the business cycle, with the risk premium rising during an economic downturn and dividends (cash flow) rising during a period of economic growth. Second, equation (4) motives the predictive regression typically seen in the asset pricing literature:

$$
r_{t+1}=\alpha+\beta x_{t}+\varepsilon_{t+1}
$$

where $r_{t+1}$ is next periods return and $x_{t}$ the predictor variable, which is typically taken to be the log dividend-price but more generally can be any variable that proxies for expected returns.

\section{Empirical Methodology.}

Based on the above discussion, our analysis utilises the usual predictive equation, albeit in a pooled context for individual firms. Thus, the general form of the model is given by:

$$
r_{i t}=\alpha+\beta x_{i t-1}+\varepsilon_{i t}
$$

Where $r_{i t}$ refers to the stock return for firm $i$ at time $t, x_{i t-1}$ refers to the predictor variables, and $\varepsilon_{i t}$ is the random error term.

In estimating the above model, there are several considerations with regard to the specification. A key motivation for using a pooled regression is to increase the available degrees of freedom in estimation and thus improve the statistical reliability of the estimates. Ang and Bekaert (2007) note that the use of pooled data should increase our confidence in the results, while it overcomes the small sample bias inherent in predictive regressions (Nelson and Kim, 1993). Given this, our pooled estimate of the slope parameter should be a reliable indicator of the average response across all firms. The next consideration is constant term. A pooled regression imposes a common constant and thus, under the null hypothesis, the same 
average return across all firms. This, of course, seems unrealistic and suggests the use of fixed (or random) effects within the regression model. ${ }^{2}$ However, with respect to this specific context, Hjalmarsson (2010) demonstrates the potential for bias within the fixed effects regression that can arise due to potential persistence and endogeneity in the predictor variable. Although, we demonstrate below that persistent is less likely to be an issue here, endogeneity may still be present. Hjalmarsson notes that the pooled regression with a common constant does not suffer from the same issue. Hence, one approach is to estimate a common constant pooled regression, such a model, with robust standard errors, is also suggested by Beck and Katz (1995). Alternatively, given that it may be preferable to eliminate firm specific information, Hjalmarsson notes, following Moon and Phillips (2000) and Sul et al (2005) that a (forward) recursive demeaning $(r d)$ approach circumvents the bias. Thus, the series are demeaned as:

$$
r_{i, t}^{r d}=r_{i, t}-\frac{1}{T-t+1} \sum_{s=t}^{T} r_{i, s}
$$

A further consideration concerns the potential for cross-section dependence in the data. Again, such effects can lead to bias in the results. Therefore, we follow the approach taken in Hjalmarsson (2010) and based on that of Pesaran (2006), in which we apply the pooled estimator to the residuals obtained from a regression of the original returns data on the crosssection average of the regressors. This implies that there are common factors within the original data and thus this procedure effectively orthogonalises the data. In reporting the estimated pooled results, we present them for three specifications, first the usual fixed effects (FE) approach, second, using the recursively demeaned (RD) data and third, using the cross-section cleaned recursively demeaned (RD-Adj) data. ${ }^{3}$

\footnotetext{
${ }^{2}$ In considering the use of, for example, a fixed effects approach, a substantial literature has developed that seeks to identify the most appropriate empirical approach, see, for example, Cameron and Miller (2105), Onali et al (2017) and Petersen (2009). In application of the fixed effects regression here, we follow this work and obtain standard errors clustered at the firm-level.

${ }^{3}$ Of course, further specifications could be considered, for example, using the common constant model, including period fixed effects or considering random effects. We believe the common constant approach does not make
} 
In the above panel regression, there are two types of variation that we can consider, providing a deeper examination of the data. From equation (6) we obtain the predictive coefficient, $\beta$, over the full sample period. This, of course, is a single constant value. However, it is likely that the coefficient will change both over individual firms within the sample and over time as both the stock market and economy go through cyclical phases. Therefore, we reestimate equation (6) in two dimensions. First, we estimate the equation for each firm individually and second, we estimate the slope parameter in equation (6) for each year separately. Hence, respectively, our equation becomes:

$$
\begin{aligned}
& r_{i t}=\alpha_{i}+\beta_{i} x_{i t-1}+\varepsilon_{i t} \\
& r_{i t}=\alpha+\beta_{t} x_{i t-1}+\varepsilon_{i t}
\end{aligned}
$$

in which either firm or time sub-scripts on the slope coefficient highlight the variation in this parameter across individual firms or time. ${ }^{4}$

We can subsequently use the varying slope parameters to examine the economic significance of the predictive variables. Notably, we can ask whether the parameter sign is consistent across the majority of the firms and time. Further, we can use the time-varying slope parameter to examine whether it has any predictive ability for future output growth, which defines the economic state variable that underpins the predictive regression.

A given predictor variable for stock returns is likely to exhibit periods of stronger and weaker predictability. While we expect a predictive coefficient to take a particular sign consistent with its economic meaning, the magnitude and, indeed, sign of the coefficient may vary depending on the phase of the business cycle. As an example, we expect a positive coefficient in the stock return predictive equation using the dividend-price ratio. A higher ratio signals either higher dividends or lower prices, both of which suggest higher future stock

\footnotetext{
economic sense to pursue, the recursive demeaning as well as further analysis below takes consideration of timevariation, while random effects may re-introduce bias as they are unlikely to be independent of the predictor variables and are not considered in this context.

${ }^{4}$ Equation (9) is estimated using a pool of two years in order to capture the lagged effect.
} 
returns. This is because either the higher dividends signal improving future economic conditions and higher future prices and returns or the lower prices suggest an increase in risk and thus higher future expected returns as compensation. ${ }^{5}$ Within the literature examining dividend-price ratio predictability, several authors have argued that the relation is timevarying. ${ }^{6}$ Notably, Henkel et al (2011) argue that the presence of counter-cyclical risk premiums means that predictability increases in a recessionary period and disappears in an expansionary one. To support the viewpoint of Henkel et al, we would expect a negative relation to exist between the dividend-price ratio predictive coefficient and output growth, i.e., there is stronger evidence of positive stock return predictability when output growth is negative. To consider this issue, we therefore, estimate:

$$
y_{t}=\mu+\delta \beta_{t-1}+v_{t}
$$

where $y_{t}$ refers to output growth and $\beta_{t}$ is the fitted value obtained from equation (9). We can estimate this regression for each of the time-varying predictive parameters and examine their ability to predict future output growth while also exhibiting economically sensible values.

In terms of the predictor variables, we include a range of financial ratios, measures of dispersion and distributional characteristics. Specially, this includes the dividend-price ratio $(D P)$, the price-earnings ratio $(P E)$, the cyclically adjusted price-earnings ratio $(C A P E)$, the payout ratio $(D E)$, the $P E$ to earnings growth ratio $(P E G)$, the Fed model $(F e d)$, returns dispersion $(R D)$, the maximum minus minimum return $(M a-M i)$, the absolute median deviation $(A M D)$, two measures of skewness (Skew NP, Skewness) and kurtosis (Kurtosis). The full definitions of these measures are presented in Table 1 together with the expected signs from the predictive regression for stock returns given in equation (6).

\footnotetext{
${ }^{5}$ There is a notable debate in the literature as to which one of these avenues dominates the expected positive relation (see for example, Cochrane, 2008; Ang, 2011; Rangvid et al, 2014).

${ }^{6}$ See, for example, Chen (2009), Guidolin et al (2013), McMillan and Wohar (2013), McMillan (2014a, 2015).
} 
Thus, we have a range of predictor variables, this includes measures that incorporate a ratio between the stock price and a variable that represents fundamental value. We also have measures that capture the variability (or risk) within stock returns and those that examine the distributional characteristic of the return series. ${ }^{7}$ In motivating the choice of these variables, we make recourse to the theoretical model outlined in Section 3. Hence, for example, each of the predictor variables can act as a proxy for future cash flow or risk in equation (4) and is linked to both future stock returns and economic conditions. This, in turn, determines the expected coefficient signs noted in Table 1.

The $D P$ and $P E$ (and $C A P E$ ) measures are considered within the context of the present value model, in which prices depend upon future discounted cash flows as measured by earnings or dividends (Campbell and Shiller, 1988). To make the results comparable, we invert the $P E$ ratio and $C A P E$ (i.e., we use the $E P$ and $C A E P$ ratio, or the earnings yield and cyclically adjusted earnings yield respectively). Thus, we expect the coefficient on each of these predictor variables to be positive. Following the present value model, a rise in dividends or earnings is associated with improving economic conditions and higher future returns, while a fall in prices, is associated will poorer economic prospects, an increase in the risk premium and a rise in future (expected) returns. Using the same theoretical approach, Lamont (1998) argues that the $D E$ will have greater predictive power for stock returns than the $D P$ or $P E$ measures. In terms of the sign of the coefficient, Lamont argues in favour of a positive relation where high dividends forecast high future returns, while high earnings are associated with high current prices, low macroeconomic risk and low future returns. The $P E G$ ratio (Farina, 1969) is defined as the $P E$ ratio divided by earnings growth and is often favoured within the practitioner literature. It is argued that this ratio allows comparison between firms that have different

\footnotetext{
${ }^{7}$ There exists a wider literature that incorporates other predictor variables, notably macroeconomic series, see, for example, Patelis (1997) who considers the role of monetary policy and Rangvid (2006) who uses a price-output, while Welch and Goyal (2008) consider a wide range of variables.
} 
growth rates as higher growth firms would have a higher $P E$ ratio but are not necessarily overvalued in comparison to a lower growth firm. In the context here, a higher $P E G$ ratio, in which a firm would have a higher price relative to fundamentals, will be associated with a lower future returns and thus a negative coefficient. The Fed model is constructed by the ratio of the earnings yield $(E P)$ to the 10-year Treasury bond. There is a significant debate about whether the Fed model is either theoretically consistent or empirical useful, but recent work reports supportive evidence (e.g., Bekaert and Engstrom, 2010; McMillan, 2012; Maio, 2013). ${ }^{8}$ Within this approach, a higher Fed value implies lower current stock prices and thus higher future expected returns, hence, we would expect to find a positive coefficient value.

The above predictor variables are based on ratios between proxies for fundamentals and stock prices. The next set of measures are designed to capture risk within the returns series as proxied by dispersion. Thus, for each of these variables, we would expect a positive coefficient in the regression with stock returns. Returns dispersion is measured as the cross-sectional standard deviation across all stocks for each year in the sample and has recently found favour as a predictor variable (e.g., Maio, 2016). Given this, we therefore also consider other measures of dispersion, namely, the spread between the maximum and minimum value in each year and the median absolute deviation. The median absolute deviation is believed to be a more robust measure of dispersion as it is less affected by outliers, in comparison to the standard deviation.

The last set of predictor variables concern distributional characteristics of the returns data. We define two measures of skewness and consider kurtosis. The first measure of skewness can be thought of as an older skewness measures and, more appropriately, the nonparametric skew statistic. This measure is the difference between the mean and median, divided by the standard deviation. The advantage of this measure is that it provides a straightforward

\footnotetext{
${ }^{8}$ For a flavour of the debate see, for example, Asness (2003), Estrada (2006) and Thomas and Zhang (2008) in addition to the above papers.
} 
description of which way the distribution leans with respect to the mean. The second measure of skewness is the more common Pearson's (third) moment coefficient of skewness. For both series, we would expect a negative coefficient as negative skewness is associated with a larger number of negative returns and thus higher risk. Our measure of kurtosis is the common Pearson (fourth) moment. A larger kurtosis value is consistent with a greater number of observations in the tails and thus more extreme values. As such, we would expect a positive coefficient value, with higher kurtosis implying greater risk and thus higher expected returns.

Therefore, for each of our firms, in addition to the stock price, we collect data on earnings and dividends, while for each market we collect 10-year Treasury bond data. This allows us to construct the different predictor variables discussed above. We also collect GDP data for each market to examine the behaviour between the predictive regression and output growth. The data is sourced from DataStream and each country's central bank and official statistics database for the interest rate and output series respectively. We also considered OECD output data, with similar results to those reported below.

\section{Stock Market Predictability.}

\subsection{Data}

The stock return, dividend and earnings data are annual observations over the time-period 1990-2014 for individual firms within key indices for ten international stock markets. We have data for Australia, Canada, France, Germany, Hong Kong, Italy, Japan, South Korea, the UK and the US. ${ }^{9}$ Specifically, we take data for all available firms in the S\&P 500 for the US, the FTSE 350 for the UK, the DAX, MDAX and SDAX for Germany, the SBF 120 for France, the MIBTEL for Italy, the TSXCOMP for Canada, the Nikkei 225 for Japan, the ASX 200 for

\footnotetext{
${ }^{9}$ The choice of countries is determined by taking the G7 markets and then the three largest markets outside of Europe and North America for which reliable data is available (the Chinese and Indian markets would be considered the largest non-G7 markets, but data availability precludes them from this analysis). The sample period is largely determined by ensuring reasonable data coverage.
} 
Australia, the Hang Seng for Hong Kong and the KOSPI for South Korea. ${ }^{10}$ As noted above, this data is obtained from DataStream, while we also collect data on 10-year Treasury Bonds and GDP. Table 2 presents summary statistics for the stock returns, with the usual characteristics of a mean value dwarfed by the standard deviation, negative skewness and evidence of non-normality provided by the Jarque-Bera statistics. ${ }^{11}$

The selection of countries analysed also provides a cross-section of markets that exhibit different characteristics that may inform any differences in results. Firms across the sample are subject to different legal and accounting standards and this may affect the reporting of earnings and the issuing of dividends. Thus, it is of interest to observe whether the results reveal systematic differences that separate along these lines. Notably, two main legal systems exist across the sample countries. Australia, Canada, Hong Kong, the UK and US are (largely) governed by common law, while France, Germany, Italy, Japan and South Korea are (largely) governed by civil law. The former system, for example, has been recognised as giving greater protection to shareholders (La Porta et al, 1999). This also promotes a market orientated financial system as opposed to a bank dominated system and the separation of countries between these two systems falls in the same fashion as the legal separation. ${ }^{12}$ A further key distinction between the countries in our sample, concerns the adoption of different accounting rules. Specifically, while IFRS has become the dominant global accounting standard in terms of country adoption, both Japan and the US, the largest two stock markets, are currently nonadopters. Whether these differences impact the results, we will consider below.

\footnotetext{
${ }^{10}$ The data set includes all firms for which sufficient data on stock prices, dividends and earnings exists and is available through the DataStream main database and 'dead' firm files.

${ }^{11}$ Our data sample includes all available firms in each index. Thus, we do not specifically exclude financial firms as often occurs in cross-sectional studies (e.g., Fama and French, 1992). We believe that the asset pricing model equally apples across different types of firm and is consistent with Nasseh and Strauss (2004) who consider all firms in the S\&P100 (except tech stocks) and McMillan (2010) who includes the financials sector in a sectoral analysis of the present value model.

12 McMillan (2014b) considers a dummy for Anglo-Saxon markets when examining predictability for stock returns, dividend and consumption growth across fifteen markets.
} 


\subsection{Empirical Results}

Before estimating the pooled regression models, we consider the degree of persistence within the predictor variables. This is because within market-level studies it is often noted that the explanatory variable, typically the dividend-price, or a similar, ratio, exhibits very high persistence. As noted above, such high persistence could bias the regression coefficient in an empirical model such as equation (6) towards rejecting the null hypothesis of no predictability. ${ }^{13}$ Thus, Table 3 presents the first-order autoregressive coefficients for each of the predictor variables. ${ }^{14}$ These persistence parameters show a noticeable discrepancy with the results reported at the market level. In Table 3, with only a few exceptions, the degree of persistence varies from being very low (and even negative) to moderate but less than 0.6. This contrasts with the typical values of around 0.99 found for market-level studies. Thus, the bias reported for market level studies is less likely to affect the regressions here. Notwithstanding this, as discussed above and following the work of Hjalmarsson (2010) we adjust our data to account for potential bias that may arise from persistence and endogeneity within the predictor variables. Furthermore, Hjalmarsson notes that in the context of a pooled model, the bias does not arise if the equation is estimated as a pooled regression. Thus, while we report results accounting for cross-sectional effect, we also consider a pooled regression, with the results, which are qualitatively similar to those reported below, available upon request.

Tables 4-7 present the panel predictive regression results for our twelve predictor variables across ten markets. ${ }^{15}$ In examining these results, we expect each of the parameters to exhibit a positive sign (except for the $P E G$ ratio and the two skewness measures) and to be

\footnotetext{
${ }^{13}$ This often referred to as the Stambaugh (1999) bias.

${ }^{14}$ The AR(1) models are estimated using the GMM dynamic panel model of Arellano and Bover (1995). This is to avoid potential bias in the autoregressive coefficient of a fixed effects panel model (Nickell, 1981).

${ }^{15}$ In estimating these models, we begin the sample period in 1995 to account for the rolling time period used for some predictors.
} 
statistically significant for the predictors to have meaningful economic and statistical content. ${ }^{16}$ We can also compare the nature of the results across the different estimation techniques and examine if, for example, the fixed effects approach provides misleading results. In Table 4, we can see that the $D P$ is positive and significant for nine of the ten markets using the fixed effects (FE) and adjusted recursive (RD-Adj) approaches, while for the recursive de-meaning (RD) approach, seven markets are statistically significant. For the (inverted) PE and CAPE ratios respectively, all ten and seven (with a further one at the $10 \%$ significance level) are positive and statistically significant using the FE approach. For the RD and RD-Adj methods and the PE ratio, six and eight markets (with two further markets at the $10 \%$ level) are statistically significant respectively. Using the RD and Rd-Adj estimators for the CAPE ratio, six markets are statistically significant (with a further market significant at the $10 \%$ level). In all cases, the parameter values are positive. Thus, these well-established ratios appear to have general predictive power for the stock returns of individual firms.

Table 5 contains a further set of financial ratios that have been suggested to contain predictive power. The payout $(D E)$ ratio is statistically significant (at the $5 \%$ or higher level) for two, three and five markets respectively across the three estimation methods (FE, RD and RD-Adj). Moreover, the sign of the coefficient is typically (but not universally) negative when the coefficient is significant (the coefficient is also negative for markets that are significant at the weaker $10 \%$ level). The $P E G$ ratio is statistically significant for four, three and four markets respectively across the estimation methods, with a positive coefficient for one market (two for the RD-Adj method, which is $10 \%$ significant for the FE and RD methods) and a negative coefficient elsewhere. Thus, these two ratios appear to convey little predictive information across our markets. That is, both in terms of statistical and economic significance, the latter

\footnotetext{
${ }^{16}$ In Tables 4-7 we also note the number of observations used in estimation. These vary across the models used depending on availability of the data for dividend and earnings across not only firms that exit the index use but also for those that are no longer trading.
} 
being in regard of the coefficient sign. In contrast, the Fed ratio, which is a ratio of the equity yield to the bond yield and has garnered much debate in academic circles, is positive and statistically significant for all ten markets for the FE approach and nine for the RD and Rd-Adj methods.

The results in these two tables cover predictability from financial ratios, we also consider measures of dispersion in Table 6 and the distribution in Table 7. Across both tables we find some generally supportive evidence of predictability, although the results are less consistent than those reported for the $D P,(C A) P E$ and Fed measures. In Table 6, for return dispersion, seven, eight and nine markets respectively have a significant coefficient across the FE, RD and RD-Adj methods. However, among these significant results, several markets exhibit a negative coefficient value. This pattern is repeated across the results for the alternative dispersion predictor variables, i.e., those based on the difference between the maximum and minimum return values and the absolute median deviation. The majority of the market exhibit statistical significance (eight, seven and nine respectively for the former predictor variable and ten, nine and nine respectively for the latter across the FE, RD and RD-Adj approaches), but within these results several markets report a negative coefficient value. Thus, although generally supportive, the presence of negative coefficient signs casts doubt on the economic validity of these predictor variables.

In Table 7, the measures of skewness and kurtosis equally provide some evidence of predictive power for stock returns, but again, we can observe inconsistency in the sign of the estimated coefficients. Thus, while we see a high degree of statistical significance, with seven markets exhibiting at least $10 \%$ significance for the non-parametric measure of skewness, nine or ten markets for the second measure of skewness and at least seven markets for the measure of kurtosis, in each case the wrong sign can be observed for at least one market, limiting the economic significance. The only exception to that is for the RD-Adj results for the Pearson's 
skewness measure. However, for the non-parametric skewness and kurtosis measures, approximately half of the coefficients across the significant results are of the wrong sign. For example, for the non-parametric skewness measure of the twenty statistically significant, at the $5 \%$ or higher, results, nine have the wrong sign. The equivalent figure for the kurtosis measure is ten out of twenty-two significant values.

This section examines predictability within firm-level stock returns for ten international markets using twelve predictor variables. Our interest here, is not just whether the predictor variables provide a significant relation with stock returns but, more importantly, whether the coefficient has the appropriate sign with respect of the underlying theoretical model and thus whether the predictor variable has economic content for stock returns. Our results suggest that the $D P, P E, C A P E$ and $F e d$ measures all exhibit the correct sign across the ten markets and are significant for the majority of the markets. Indeed, across at least two empirical methods, for the $D P, P E$ and $F e d$ ratios, the coefficients are statistically significant for at least nine and, on at least one empirical method, all ten markets. For the remaining predictor variables, they either exhibit very limited statistical significance (for example, the $D E$ and $P E G$ ratios) or exhibit mixed coefficient signs (for example, the measures of dispersion and distribution). Thus, for these latter measures, with one exception noted below, while statistical significance supports a predictive effect, the inconsistent coefficient signs, cast doubt on the economic content of these predictor variables.

We can consider this latter point further and whether there is any commonality across the markets with wrong signed or insignificant coefficients in respect of the country characteristics identified in Section 5.1. We can see, above, that the $D E$ ratio is predominately negative but with limited significance, whereas Lamont (1988) argues in favour of a positive sign. The $P E G$ ratio is mixed in terms of coefficient sign and significance and suggests little predictive power. The measures of dispersion typically have the correct sign, however, across 
each measure there is at least one instance of a significant wrong signed coefficient. Likewise, for the measures of distribution, there is evidence of significant positive and negative coefficient signs. An exception to this is the RD-Adj approach for rolling (Pearson) skewness, which is correctly signed and significant for all markets. In asking whether there is any commonality across the markets, we can see that no such consistency is evident. For example, across the $D E$ results we see a significant negative coefficient for Australia, Germany, Japan and the US and thus these markets cross the common and civil law and adoption and nonadoption of IFRS characteristics noted above. Likewise, as a further example, for the nonparametric skewness measure, Australia and the UK have opposing coefficient signs but are both characterised by common law systems and IFRS adoption. Instead, the nature of the results may simply reflect the ability of the given series to proxy for expected returns across a broad range of international markets.

Of further interest, we can consider whether the results obtained from the different empirical approaches reveal consistent results. Across the FE, RD and RD-Adj approaches, we see a broadly consistent pattern in both the sign and significance of the coefficients. While there are some differences, the overall picture across markets and predictors is qualitatively similar. That said, the most noticeable difference is observed with the Pearson skewness measure, which under the RD-Adj approach does provide a consistent (negative) coefficient sign and is statistically significant for all ten markets. ${ }^{17}$ Thus, while most of results are consistent, this does suggest the importance of properly addressing any econometric concerns to ensure inference is robust.

\footnotetext{
${ }^{17}$ A change in sign is also observed for the return dispersion predictor for the US.
} 


\section{Variation.}

The results presented above in the pool regressions essentially capture the average response of all firms in each market across the full sample period. The use of pooling techniques has the advantage of increasing the degrees of freedom in estimation and thus the accuracy of the coefficient values. However, a downside to pool estimation is that there will exist variation in the cross-section elements, such that there is some loss of information within the results. That is, the estimated pool coefficient represents an average response and within that average there will be dispersion among the coefficients of individual firms. There will also exist variation across time (although this applies equally to all regressions and not just pool models). Indeed, this issue has been considered before by, among others, Park (2010), McMillan (2014a, 2015), McMillan and Wohar (2013). Therefore, to address these issues, we first, estimate the predictive equation across all individual firms, equation (8), and second, we estimate the regression over time. Moreover, we consider this time-variation in two ways, first, we isolate the financial crisis period by introducing a dummy variable for the years 2007-2009 and second, we estimate equation (9) that allows the slope coefficient to vary with each year.

Table 8 presents a description of the results for equation (8) where we estimate our predictive equation for each individual firm. We report in this table the proportion of positive coefficient values for each market for all cross-sections, recalling that for the estimation results to have any economic meaning we would expect the slope coefficients to be positive (except for the $P E G$ ratio and the two measures of skewness). Specifically, we estimate the predictive equation individually for each firm in our sample and the number reported in Table 8 is the number of times, as a percentage, the predictive coefficient in the individual firm regressions is positive across all firms in each market.

Before we examine the results within the table, Figure 1 illustrates the general pattern we find across the different markets and predictor variables. Figure 1 presents the individual 
firm coefficients for the UK using the (inverse) price-earnings ratio. Evident in this figure is that while most of firms exhibit the correct positive coefficient sign, nonetheless, a number of firms report a negative value. Thus, while the predictor variable has a consistent economic message for most firms, it is not the case for every firm.

Taking a view of the number of times each predictor variable has the correct sign, we can see that the $C A P E$ ratio is preferred, obtaining an average number of correct signs in $84 \%$ of the regressions for all individual firm cross-sections (reported in the last column of the table). An above $70 \%$ average is also achieved by DP, PE, Fed and (Pearson) Skewness (recalling that its sign should be negative). The rest of the predictor variables fall below an average $70 \%$ sign success rate, which would question their ability to provide a robust economic reason for predictability. Taking these preferred five models and looking closer at their performance across the ten markets, we can consider their lowest success rate and the number of times the success rate for any given market falls below $70 \%$. For the $D P$, the lowest percentage of positive coefficients is $62 \%$ for Australia, while for three markets the percentage falls below $70 \%$ (Australia, Canada and Italy). For PE, the lowest success rate is 57\% (Italy), while success falls below $70 \%$ for four markets (Australia, Canada, Germany and Italy). For CAPE, the lowest proportion of correct signs is $70 \%$ (Italy) and thus no market falls below that level. For the Fed and Skewness predictor variables the lowest correct signs rate is $58 \%$ and $41 \%$ respectively (both Italy), while sign success falls below $70 \%$ four times for the $\mathrm{Fed}$ variable (Australia, Canada, Italy and South Korea) and three times for Skewness (Canada, Hong Kong and Italy).

These results thus reveal that the CAPE predictor variable performs the best in economic terms by obtaining the correct coefficient sign the most times across the ten markets. Of the alternative predictor variables, the ratio measures of the $D P, P E$ and $F e d$ perform well while the Skewness variable is the only distributional variable that achieves a reasonable 
performance. These results thus provide some consistency with the full sample results and further support for the $D P, P E, C A P E$ and Fed ratios. Equally, the support for the Skewness measure here is consistent with the RD-Adj results reported above.

As noted, we consider time-variation in two ways. Table 9 repeats the estimation results of Tables 4-7 but now including a dummy variable (both intercept and slope) for the financial crisis years of 2007-2009, while Table 10 presents a similar exercise to that reported in Table 8 but for the time-varying coefficients. In analysing the results in Table 9, we can see a distinction between the results for the ratios and those for dispersion and the distribution (with one exception) that largely reflect the full sample results above. Examining the results for the $D P, P E, C A P E$ and Fed ratios, we can see that the positive relation reported in Tables 4 and 5 is strengthened during the financial crisis period with a positive and nearly wholly significant coefficient. For the $D E$ and $P E G$ ratios, the mixed picture of results from Table 5 is repeated, with evidence of a significant financial crisis dummy occurring for less than half the markets considered and with no consistent coefficient sign. For the dispersion measures, we see a positive and frequently significant coefficient during the crisis period. However, there are exceptions to this, for example the Max-Min variable for Canada and the US. Moreover, we observe a more mixed picture during the non-crisis periods than suggested by the results in Table 6, with the coefficient now typically insignificant. This suggests that the predictive power of dispersion variables largely only arises during a crisis when dispersion across individual stocks in heightened. ${ }^{18}$ For the distribution series, we see that the result for the rolling skewness measure is similar to that of the ratio series. The strength of the expected (negative) coefficient is heightened during the crisis period and indeed for Canada and France it overturns the positive

\footnotetext{
${ }^{18}$ For example, the average value for US return dispersion during the crisis is 0.38 in contrast to 0.20 in the period after and 0.31 in the period prior (which also includes the dotcom bubble crash).
} 
non-crisis period sign. For the non-parametric skewness measure and the kurtosis measure, the signs and significance of the coefficients remain mixed as observed for the full sample results.

The entries in Table 10 represent the percentage number of times the coefficient for each predictor variable and market are positive across a pool regression over each time period as given by equation (9). Again, we can illustrate the nature of the results in Figure 2, which reports the coefficient for the (inverse) price-earnings ratio for the UK, together with two times the standard error bands. Here, we can observe time-variation, with the coefficient becoming negative around notable periods of market stress such as the dotcom crash and the financial crisis. The inclusion of the standard error bands also allows us to observe that statistical significance also varies over time.

In Table 10, we can see that the financial ratios, except $P E G$, tend to report the expected coefficient sign over time more than the distributional variables (recalling that the $P E G$ ratio and the two skewness measures are expected to have a negative sign). Notably, the average percentage number of correct signs are $65 \%, 64 \%$ and $63 \%$ for $C A P E, D P$ and $P E$ respectively. The $D E$ and $F e d$ perform slightly worse at $61 \%$, while the best performing distributional variable is Skew NP at $60 \%$ (again, we expect a negative coefficient).

Examining these results in greater detail, we can see that the same four predictor variables, $D P, P E, C A P E$ and $F e d$ ratios, appear to perform better than all other predictor variables. Here, they all achieve a success rate in terms of the positive coefficient of no lower than $50 \%$ (55\% for the DP and CAPE ratios). Every other predictor exhibits a less than 50\% success rate for at least one market. Of interest, of the remaining, distributional, variables, the non-parametric skewness measure now performs best in contrast to the Pearson skewness measure that previously had performed well.

These results suggest greater variation in the coefficient values across time than across individual firms, although it should be borne in mind that there is significantly fewer time series 
periods than cross-section observations and thus a comparison may be misleading. Notwithstanding this, and looking across both these tables, these results continue to support the use of the key financial ratios used within the literature as providing economic content, notably the $D P, P E$ and $C A P E$ ratios. The results also support the Fed ratio as providing economically meaningful coefficients, thus, supporting its use despite its contentious nature as noted above. The $D E$ and $P E G$ ratios are less successful in providing the expected coefficient sign. The distributional variables typically achieve the correct sign in over half the cases, although they generally perform worse the above noted financial ratios and often perform particularly poorly for at least one market, casting doubt on their general use.

\section{Predictive Power and Output.}

In the above section, we examine the economic significance of the predictor variables by considering whether they report the expected coefficient sign. In this section, we consider the economic significance of the predictor variables from a different perspective. A predictive relation exists as expectations about future economic performance are reflected in the predictor variables and stock returns. As can be seen by equation (4) in Section 2, stock return predictability arises through variables that proxy for future cash flow and risk, and thus future economic conditions. The strength of the predictive relation will reflect the confidence investors feel about their future expectations. Thus, a strengthening of the predictive relation should itself have predictive power for output growth. For example, we expect a positive relation between $D P$ and stock returns, which can arise either through a cash flow or risk premium channel. An increase in the slope coefficient within this relation implies that the economic strength of predictive power increases. This can then have a positive predictive effect on output growth through the cash flow channel where higher dividends signal improving expected economic performance, or a negative predictive effect through the risk channel where 
lower prices signal a weakening of economic conditions. We can make similar arguments across the predictor variables and thus for the predictive relation to have economic content, we would expect the time-varying coefficient to be related with future output growth.

An increasing amount of empirical evidence at the market level has identified timevariation within the predictive relation (as we do here) and link that time-variation with the state of the economy. Henekel et al (2011) argue the predictive relation of equation (5) is only evident during an economic contraction. Guidolin et al (2013) show that movement in the timevarying predictive parameter is related to output as measured by the growth rate of industrial production. A further line of research shows that the predictor variables (typically the dividendprice ratio) may be related to macroeconomic variables, typically consumption (e.g., Campbell, 2003; Bansal and Yaron, 2004; McMillan, 2013). The nature of this relation again arises through expectations surrounding future economic conditions. A rising dividend-price ratio can be positively related to future output (and consumption) through the cash flow channel as higher dividends signal an improving economy and higher future output (consumption). Alternatively, the relation can be negative as a falling stock price indicates poorer future economic conditions and lower output (consumption). Empirical evidence equally shows that this relation can be time-varying (McMillan, 2014b, 2015).

Thus, the predictor variables for stock returns can also predict future output and in both cases the relation is time-varying. Furthermore, stock returns can predict future output (Mauro, 2003; Henry et al, 2004; Tay, 2007) with the generally supported view that such predictability arises as positive economic news is reflected in stock prices before it can be seen in output measures. Tying these strands together, we argue that an increase in the strength of stock return predictability (an increase in the absolute value of the predictive coefficient) implies that investors are more confident in their view of future economic conditions and the time-varying coefficient should, therefore, have predictive power for output growth. Hence, we estimate 
equation (10) and consider whether the predictor variables and the resulting the time-varying parameters contain any economic information.

Table 11 reports the results of equation (10) across all our markets and predictive variables. Taking an overall view for each predictor variable, for the variable to contain economic meaning, we would expect it to have the same sign across all markets and exhibit statistical significance. In terms of the relation between output growth and predictive strength, for $D P, P E, C A P E$ and the Fed ratios, there is a positive sign for all ten markets. Furthermore, these relations are statistically significant at the 5\% level (or higher) for eight, seven, nine and five markets respectively. In addition, several results are also significant at the $10 \%$ level, for the $P E$ (one market), $C A P E$ (one market) and Fed (four markets), indicating a reasonable level of statistical significance across almost all markets. For the $D E$ and $P E G$ ratios, nine and eight markets have the same signed relation with output growth, although the level of statistical significance is notably reduced, with only five and two markets respectively significant at the $5 \%$ level (with an additional two and one markets significant at the $10 \%$ level respectively). These results support the view that movement in the strength of predictive power arising from financial ratios is linked to movements in expected future economic conditions.

For the predictor variables based on stock return dispersion and distributional characteristics, there is notably less consistency in the results between predictive strength and output growth. For example, the return dispersion predictive coefficient has five markets with a positive relation and five with a negative relation, but very limited significance, both one $5 \%$ significant positive and negative relation. The same pattern is seen across the other predictor variables. The absolute median deviation, which has the highest number of similar signs (seven positive relations), only has two statistically significant relations at the 5\% level. Equally, for the skewness and kurtosis predictor coefficients, there is only very limited evidence of significance and that occurs for both positive and negative values. 
We can consider the nature of the relations for the above four identified predictor variables, $D P, E P, C A P E, F e d$, in greater detail. Each of these variables has a positive predictive relation with stock returns. This implies that an increase in dividends or earnings is associated with an increase in expected future stock returns. An alternative view is that the positive relation with stock returns arises from falling stock prices. These two justifications for the positive relation essentially capture the cash flow versus discount rate views of asset price movement. As noted above, we also observe a positive relation between the predictive coefficient and output growth. This suggests that a strengthening of stock return predictive power is associated with an increase in future economic conditions (equally, a weakening of predictive power is associated with poorer expected economic conditions). This viewpoint is more consistent with the cash flow route in explaining stock return predictability. Thus, a strengthening of the predictive relation occurs as investors become more certain about the future course of the economy. A rise in dividends is associated with higher future stock returns and the nature of that relation strengthens as investors become confident about an upturn in future economic conditions. If predictability arose through the discount rate channel, then we would expect to see a negative relation between the strengthening of predictability and future output growth as the predictability arise due to an increase in economic risk. ${ }^{19}$

\section{Summary and Conclusion.}

This paper considers whether popular predictor variables for market level index returns also exhibit predictive power for individual firm level returns across a range of international markets. We obtain firm level data for ten international stock markets. This includes price, earnings and dividend data. We also obtain data on 10-year Treasury bond yields and output. Using this data, we generate twelve predictor variables, including price ratios and measures of

\footnotetext{
${ }^{19}$ This counter-cyclical risk premium view is espoused by Henkel et al (2011).
} 
dispersion and distribution. Using three pool regression approaches, we estimate stock return predictive models for each variable individually and consider both the statistical and economic significance, the latter is achieved through an examination of the coefficient sign. In addition to the pool regression, we consider variation within the nature of the results by conducting the predictive regression across both individual firms and time periods, including a separate analysis for the financial crisis. Subsequently, we use the time-varying coefficients to examine their relation with future output growth, enhancing the economic interpretation of the results.

Our results suggest the following key conclusions. Over the full sample, four predictor variables have estimated coefficients that are consistently of the expected sign and are statistically significant across markets and estimation methods. These are the $D P, P E, C A P E$ and Fed ratios. The same four variables are also notable in having the economically correct sign for the greatest number of firms and time periods when examining variation within the predictive relations. Equally, these four variables exhibit a significant positive relation with future output growth and thus provide a set of results that demonstrates both statistical and economic significance. It is also notable that other price ratio measures ( $D E$ and $P E G$ ratios) as well as measures of both dispersion and distribution do not provide such supportive evidence of both statistical and economic significance. These results thus provide evidence that only some of the predictor variables examined within the literature contain economic significance and could be regarded as meaningful predictors that are likely to exhibit continued predictability in future samples of data as they are linked to the underlying economic state variable. Of further interest, the results across the three estimation methods are broadly consistent in terms of coefficient sign and significance. However, one exception exists (for the skewness measure) where the preferred cross-section adjusted recursive de-meaned approach differs from the fixed effects or non-adjusted recursive de-meaned approaches. Although this 
difference is only noted for one of the twelve predictor variables it does highlight the need to ensure robust estimation in order to arrive at the correct inference.

We can also use our results to draw inference about the nature of the relation between financial markets and the real economy. The results from the above four (DP, PE, CAPE and $\mathrm{Fed}$ ) ratios all exhibit a positive relation with stock returns. Each ratio is constructed with dividends or earnings as a ratio to stock prices (and for the Fed ratio, then to 10-year Treasury bonds). The positive relation with stock returns arises either from a rise in dividends or earnings or a fall in stock prices and, hence, either positive expected future economic conditions (thus, rising dividends and earnings) or negative future expectations (thus, falling prices). These two alternative views are referred to as the cash flow and risk premium channels. To understand which of these avenues explains the positive stock return relation, we can use the output growth and time-varying coefficient results. Here, the positive relation between output growth and the time-varying predictive coefficient across all series, suggests that the expectation of improving future economic conditions, leads to a strengthening of the positive stock return predictive relation and thus, the cash flow channel dominates.

The results here provide some general implications that are of relevance to both academics and investors. In academic research, there is a desire to understand the drivers of stock price movement and the theoretical models that link stocks with the wider economy. For investors, while much academic research examines market level index behaviour, such indices are not investible (notwithstanding ETFs). Therefore, there is a need to understand the behaviour of (investible) stocks, which may display different characteristics from indices. The strong results for the price ratios (and the dividend-price and price-earnings ratios in particular) provide support for the present value model. This supports previous research that confirms this relation at the firm level more than at the market level. The supportive results for the Fed model 
highlight the importance of the relation with interest rates. ${ }^{20}$ In developing this research, it is of interest to examine further predictor variables, including those linked more explicitly to the macroeconomy including, for example, output growth, unemployment and inflation. Further, expanding the range of market to include emerging (and frontier) markets, would provide a fuller understanding of stock return movements. In addition, a further extension would be to conduct a more detailed investigation into the observed cross-country differences in some results. While, we observe broad consistency in coefficient sign and significance for several ratios (for example, the $D P, P E, C A P E$ and $F e d$ measures), there is more distinction across countries in the dispersion and distribution variables. Our results suggest that such a distinction cannot be explained by differences between common and civil laws and IFRS adoption and thus leaves open as an avenue of further research to explain such differences.

\footnotetext{
${ }^{20}$ For example, Harvey (1989) argues that the bond market can provide greater predictive power for output than the stock market.
} 


\section{References}

Amaya, D., Christoffersen, P., Jacobs, K., \& Vasquez, A. (2015). Does realized skewness predict the cross-section of equity returns? Journal of Financial Economics, 118, 135-167.

Ang, A. (2011). Predicting dividends in log-linear present value models. Pacific-Basin Finance Journal, 20, 151-171.

Ang, A., \& Bekaert, G. (2007). Stock return predictability: Is it there? Review of Financial Studies, 20, 651-707.

Arellano, M., \& Bover, O. (1995). Another look at the instrumental variable estimation of error-components models. Journal of Econometrics, 68, 29-51.

Asness, C. (2003). Fight the Fed model: the relationship between future returns and stock and bond market yields. Journal of Portfolio Management, 30, 11-24.

Bansal, R., \& Yaron, A. (2004). Risks for the long run: A potential resolution of asset pricing puzzles. Journal of Finance, 59, 1481-1509.

Beck, N., \& Katz, J.N. (1995). What to do (and not to do) with time-series cross-section data. American Political Science Review, 89, 634-647.

Bekaert, G., \& Engstrom, E. (2010). Inflation and the stock market: Understanding the Fed model. Journal of Monetary Economics, 57, 278-294.

Bulkley, G., \& Taylor, N. (1996). A cross-section test of the present value model. Journal of Empirical Finance, 2, 295-306.

Cameron, A.C., \& Miller, D.L. (2015). A practitioner's guide to cluster-robust inference. Journal of Human Resources, 50, 317-372.

Campbell, J.Y. (2003). Consumption-based asset pricing. In G. Constantimidis, M. Harris, \& R. Stulz (Eds), Handbook of the Economics of Finance (pp. 803-887). Amsterdam: NorthHolland.

Campbell, J.Y., \& Shiller, R.J. (1988). The dividend-price ratio and expectations of future dividends and discount factors. Review of Financial Studies, 1, 195-228.

Campbell, J.Y., \& Thompson, S.B. (2008). Predicting excess stock returns out of sample: Can anything beat the historical average? Review of Financial Studies, 21, 1509-1531.

Chen, L. (2009). On the reversal of return and dividend growth predictability: A tale of two periods. Journal of Financial Economics, 92, 128-151.

Cochrane, J. (2008). The dog that did not bark: A defense of return predictability. Review of Financial Studies, 21, 1533-1575.

Cochrane, J. (2011). Discount rates: American finance association presidential address. Journal of Finance, 66, 1047-1108. 
Cooper, I., \& Priestley, R. (2009). Time-varying risk premiums and the output gap. Review of Financial Studies, 22, 2801-2833.

Cooper, I., \& Priestley, R. (2013). The world business cycle and expected returns. Review of Finance, 17, 1029-1064.

Estrada, J. (2006). The Fed model: The bad, the worse and the ugly. IESE Business School working paper.

Fama, E.F., \& French, K.R. (1988). Dividend yields and expected stock returns. Journal of Financial Economics, 22, 3-25.

Fama, E.F., \& French, K.R. (1992). The cross-section of expected returns. Journal of Finance, 47, 427-465.

Farina, M.V. (1969). A Beginner's Guide to Successful Investing in the Stock Market. New Jersey: Investors' Press.

Goddard, J., McMillan, D.G., \& Wilson, J. (2008). Dividends, prices and the present value model: Firm-level evidence. European Journal of Finance, 14, 195-210.

Guidolin, M., McMillan, D.G., \& Wohar, M.E. (2013). Time-Varying Stock Return Predictability: Evidence from US Sectors. Finance Research Letters, 10, 34-40.

Hammerschmid, R., \& Lohre, H. (2018). Regime shifts and stock return predictability. International Review of Economics and Finance, 56, 138-160.

Harvey, C.R. (1989). Forecasts of economic growth from the bond and stock markets. Financial Analyst Journal, 45, 38-45.

Henkel, S.J., Martin, J.S., \& Nardari, F. (2011). Time-varying short-horizon predictability. Journal of Financial Economics, 99, 560-580.

Henry, O.T., Olekalns, N., \& Thong, J. (2004). Do stock market returns predict changes to output? Evidence from a nonlinear panel data model. Empirical Economics, 29, 527-540.

Hjalmarsson, E. (2010). Predicting global stock returns. Journal of Financial and Quantitative Analysis, 45, 49-80.

Jung, J., \& Shiller, R.J. (2005). Samuelson's dictum and the stock market. Economic Inquiry, $43,221-228$.

Kellard, N.M., Nankervis, J.C., \& Papadimitriou, F.I. (2010). Predicting the equity premium with dividend ratios: Reconciling the evidence. Journal of Empirical Finance, 17, 539-551.

Lamont, O. (1998). Earnings and expected returns. Journal of Finance, 53, 1563-1587.

Laopodis, N.T. (2016). Industry returns, market returns and economic fundamentals: Evidence for the United States. Economic Modelling, 53, 89-106. 
La Porta, R., Lopez-deSilanes, F., Shleifer, A., \& Vishny, R.W. (1999). Investor Protection: Origins, Consequences, and Reform. NBER Working Paper No. 7428.

Lettau, M., \& Van Nieuwerburgh, S. (2008). Reconciling the return predictability evidence. Review of Financial Studies, 21, 1607-1652.

Lewellen, J. (2004). Predicting returns with financial ratios. Journal of Financial Economics, 74, 209-235.

Maio, P. (2013). The Fed model and the predictability of stock returns. Review of Finance, 17, $1489-1533$.

Maio, P. (2016). Cross-sectional return dispersion and the equity premium. Journal of Financial Markets, 29, 87-109.

Mauro, P. (2003). Stock returns and output growth in emerging and advanced economies. Journal of Development Economics, 71, 129-153.

McMillan, D.G. (2003). Non-linear predictability of UK stock market returns. Oxford Bulletin of Economics and Statistics, 65, 557-573.

McMillan, D.G. (2010). Present value model, bubbles and returns predictability: Sector-level evidence. Journal of Business Finance and Accounting, 37, 668-686.

McMillan, D.G. (2012). Does non-linearity help us understand, model and forecast UK stock and bond returns: evidence from the BEYR. International Review of Applied Economics, 26, 125-143.

McMillan, D.G. (2013). Consumption and stock prices: Evidence from a small international panel. Journal of Macroeconomics, 36, 76-88.

McMillan, D.G. (2014a). Modelling time-variation in the stock return-dividend yield predictive equation. Financial Markets, Institutions and Instruments, 23, 273-302.

McMillan, D.G. (2014b). Stock returns, dividend growth and consumption growth predictability: Variation across markets and time. International Review of Financial Analysis, $35,90-101$.

McMillan, D.G. (2015). Time-varying predictability for stock returns, dividend growth and consumption growth. International Journal of Finance and Economics, 20, 362-373.

McMillan, D.G., \& Wohar, M.E. (2010). Stock return predictability and dividend-price ratio: A nonlinear approach. International Journal of Finance and Economics, 15, 351-365.

McMillan, D.G., \& Wohar, M.E. (2013). A panel analysis of the stock return dividend yield relation: predicting returns and dividend growth. Manchester School, 81, 386-400.

Moon, H.R., \& Phillips. P.C.B. (2000). Estimation of autoregressive roots near unity using panel data. Econometric Theory, 16, 927-998. 
Nasseh, A., \& Strauss, J. (2004). Stock prices and the dividend discount model: Did their relation break down in the 1990s? Quarterly Review of Economics and Finance, 44, 191-207.

Nelson, C.R., \& Kim, M.J. (1993). Predictable stock returns: the role of small sample bias. Journal of Finance, 48, 641-661.

Nickell, S. (1981). Biases in dynamic models with fixed effects. Econometrica, 49, 1417-1426.

Onali, E., Ginesti, G., \& Vasilakis, C. (2017). How should we estimate value-relevance models? Insights from European data. British Accounting Review, 49, 460-473.

Park, C. (2010). When does the dividend-price ratio predict stock returns? Journal of Empirical Finance, 17, 81-101.

Patelis, A.D. (1997). Stock return predictability and the role of monetary policy. Journal of Finance, 52, 1951-1972.

Paye, B., \& Timmermann, A. (2006). Instability of return prediction models. Journal of Empirical Finance, 13, 274-315.

Pesaran, M.H. (2006) Estimation and inference in large heterogeneous panels with a multifactor error structure. Econometrica, 74, 967-1012.

Petersen, M.A. (2009). Estimating standard errors in finance panel data sets: Comparing approaches. Review of Financial Studies, 22, 435-480.,

Psaradakis, Z., Sola, M., \& Spagnolo, F. (2004). On Markov switching error-correction models, with an application to stock prices and dividends. Journal of Applied Econometrics, 19, 68-88.

Rangvid, J. (2006). Output and expected returns. Journal of Financial Economics, 81, 595624.

Rangvid, J., Schmeling, M., \& Schrimpf, A. (2014). Dividend predictability around the world. Journal of Financial and Quantitative Analysis, 49, 1255-1277.

Stambaugh, R. (1999). Predictive regressions. Journal of Financial Economics, 54, 375-421.

Sul, D., Phillips, P.C.B., \& Choi, C.Y. (2005). Prewhitening bias in HAC estimation. Oxford Bulletin of Economics and Statistics, 67, 517-546.

Tay, A.S. (2007). Mixing frequencies: Stock returns as a predictor of real output growth. Discussion Paper, SMU.

Timmermann, A. (2008). Elusive return predictability. International Journal of Forecasting, 24, 1-18.

Thomas, J., \& Zhang, F. (2008). Don't fight the Fed model! School of Management, Yale University, Working Paper. 
Vuolteenaho, T. (2002). What drives firm-level stock returns? Journal of Finance, 57, 233264.

Welch, I., \& Goyal, A. (2008). A comprehensive look at the empirical performance of equity premium prediction. Review of Financial Studies, 21, 1455-1508. 
Table 1. Predictor Variable Definitions and Expected Coefficient Signs

\begin{tabular}{|c|c|c|}
\hline Predictor Variable & Definition & Expected Sign \\
\hline Dividend-Price Ratio (DP) & $\begin{array}{l}\text { The latest announced } \\
\text { dividend divided by the } \\
\text { latest (current) price }\end{array}$ & Positive \\
\hline $\begin{array}{l}\text { Inverted Price-Earnings } \\
\text { Ratio (PE) }\end{array}$ & $\begin{array}{l}\text { The latest announced } \\
\text { earning divided by the latest } \\
\text { (current) price }\end{array}$ & Positive \\
\hline $\begin{array}{c}\text { Inverted Cyclically Adjusted } \\
\text { Price-Earnings Ratio } \\
\text { (CAPE) }\end{array}$ & $\begin{array}{l}\text { Trailing five year moving } \\
\text { average of announced } \\
\text { earning divided by the latest } \\
\text { (current) price }\end{array}$ & Positive \\
\hline $\begin{array}{l}\text { Payout, or Dividend to } \\
\text { Earnings, Ratio (DE) }\end{array}$ & $\begin{array}{l}\text { The latest announced } \\
\text { dividend divided by the } \\
\text { latest announced earnings }\end{array}$ & Positive \\
\hline $\begin{array}{c}\text { Price to Earnings Growth } \\
\text { Ratio (PEG) }\end{array}$ & $\begin{array}{l}\text { The PE ratio dividend by the } \\
\text { latest announced earnings } \\
\text { growth }\end{array}$ & Negative \\
\hline The Fed Ratio (Fed) & $\begin{array}{l}\text { The earnings yield (latest } \\
\text { announced earnings } \\
\text { dividend by the current } \\
\text { price) dividend by the 10- } \\
\text { year Treasury bond yield }\end{array}$ & Positive \\
\hline Returns Dispersion (RD) & $\begin{array}{l}\text { The cross-sectional standard } \\
\text { deviation for each year in } \\
\text { the sample }\end{array}$ & Positive \\
\hline $\begin{array}{l}\text { Maximum minus Minimum } \\
\text { Stock Returns (Ma-Mi) }\end{array}$ & $\begin{array}{c}\text { The difference in the cross- } \\
\text { sectional maximum and } \\
\text { minimum stock return } \\
\text { values }\end{array}$ & Positive \\
\hline Absolute Median Deviation & $\begin{array}{l}\text { The cross-sectional median } \\
\text { value of the absolute } \\
\text { deviation of stock returns } \\
\text { from their median value }\end{array}$ & Positive \\
\hline $\begin{array}{c}\text { Non-Parametric, or Old, } \\
\text { Skewness measure (Sk NP) }\end{array}$ & $\begin{array}{c}\text { The difference between the } \\
\text { mean and median values } \\
\text { divided by the standard } \\
\text { deviation }\end{array}$ & Negative \\
\hline $\begin{array}{c}\text { Pearson's Moment } \\
\text { Coefficient of Skewness } \\
\text { measure }\end{array}$ & $\begin{array}{l}\text { The third conditional } \\
\text { standardised moment; ratio } \\
\text { of the third cumulant to the } \\
1.5 \text { th power of the second } \\
\text { cumulant }\end{array}$ & Negative \\
\hline $\begin{array}{c}\text { Pearson's Moment } \\
\text { Coefficient of Kurtosis } \\
\text { measure } \\
\end{array}$ & $\begin{array}{l}\text { The fourth conditional } \\
\text { standardised moment. }\end{array}$ & Positive \\
\hline
\end{tabular}


Table 2. Summary Statistics for Stock Returns

\begin{tabular}{|c|c|c|c|c|c|}
\hline Market & Mean & $\begin{array}{c}\text { Standard } \\
\text { Deviation }\end{array}$ & Skewness & Kurtosis & Jarque-Bera \\
\hline Australia & $0.031^{\mathrm{a}}$ & 0.614 & -0.197 & 3.053 & $37.29^{\mathrm{a}}$ \\
\hline Canada & $0.094^{\mathrm{a}}$ & 0.486 & -0.256 & 3.574 & $88.50^{\mathrm{a}}$ \\
\hline France & $0.053^{\mathrm{a}}$ & 0.374 & -0.597 & 3.866 & $64.36^{\mathrm{a}}$ \\
\hline Germany & $0.056^{\mathrm{a}}$ & 0.364 & -0.494 & 3.655 & $32.28^{\mathrm{a}}$ \\
\hline Hong Kong & $0.094^{\mathrm{a}}$ & 0.447 & -0.188 & 3.153 & $5.14^{\mathrm{c}}$ \\
\hline Italy & $-0.025^{\mathrm{b}}$ & 0.451 & -0.236 & 3.198 & $46.55^{\mathrm{a}}$ \\
\hline Japan & -0.001 & 0.402 & -0.099 & 3.450 & $40.96^{\mathrm{a}}$ \\
\hline South Korea & $0.051^{\mathrm{a}}$ & 0.526 & -0.043 & 2.762 & $7.85^{\mathrm{b}}$ \\
\hline UK & $0.057^{\mathrm{a}}$ & 0.418 & -0.369 & 3.735 & $414.41^{\mathrm{a}}$ \\
\hline US & $0.099^{\mathrm{a}}$ & 0.381 & -0.385 & 3.918 & $517.19^{\mathrm{a}}$ \\
\hline
\end{tabular}

Notes: Entries are summary statistics for stock returns within each country. The superscript letters a, b, c refer to $1 \%, 5 \%$, and $10 \%$ statistical significance level respectively. 
Table 3. GMM AR(1) Parameter of Financial Ratios

\begin{tabular}{|c|c|c|c|c|c|c|c|c|c|c|}
\hline & Aus & Can & Fra & Ger & HK & Ity & $\mathrm{Jp}$ & S. Kor & UK & US \\
\hline DP & $\begin{array}{l}0.164^{\mathrm{a}} \\
(5.84)\end{array}$ & $\begin{array}{l}0.338^{\mathrm{a}} \\
(9.38)\end{array}$ & $\begin{array}{l}0.474^{\mathrm{a}} \\
(6.98)\end{array}$ & $\begin{array}{l}0.477^{\mathrm{a}} \\
(5.20)\end{array}$ & $\begin{array}{l}0.216^{\mathrm{a}} \\
(4.01)\end{array}$ & $\begin{array}{l}0.228^{\mathrm{a}} \\
(6.01)\end{array}$ & $\begin{array}{l}0.516^{\mathrm{a}} \\
(8.27)\end{array}$ & $\begin{array}{c}0.292^{\mathrm{a}} \\
(10.96)\end{array}$ & $\begin{array}{l}0.217^{\mathrm{a}} \\
(5.99)\end{array}$ & $\begin{array}{l}0.113^{b} \\
(2.04)\end{array}$ \\
\hline $\mathrm{PE}$ & $\begin{array}{c}0.013 \\
(0.82)\end{array}$ & $\begin{array}{c}0.045 \\
(1.05)\end{array}$ & $\begin{array}{l}0.195^{\mathrm{a}} \\
(5.06)\end{array}$ & $\begin{array}{l}0.286^{\mathrm{a}} \\
(6.79)\end{array}$ & $\begin{array}{l}0.317^{\mathrm{a}} \\
(4.55)\end{array}$ & $\begin{array}{l}0.049^{b} \\
(2.55)\end{array}$ & $\begin{array}{l}0.170^{\mathrm{a}} \\
(5.52)\end{array}$ & $\begin{array}{l}0.004 \\
(0.40)\end{array}$ & $\begin{array}{l}0.293^{\mathrm{a}} \\
(3.93)\end{array}$ & $\begin{array}{l}0.029 \\
(1.18)\end{array}$ \\
\hline CAPE & $\begin{array}{l}0.177^{\mathrm{a}} \\
(4.27)^{2}\end{array}$ & $\begin{array}{c}0.454^{\mathrm{a}} \\
(17.56)\end{array}$ & $\begin{array}{c}0.535^{\mathrm{a}} \\
(14.28)\end{array}$ & $\begin{array}{c}0.784 \mathrm{a} \\
(4.86)\end{array}$ & $\begin{array}{c}0.686^{a} \\
(32.35)\end{array}$ & $\begin{array}{l}0.492^{\mathrm{a}} \\
(7.10)\end{array}$ & $\begin{array}{l}0.809^{\mathrm{a}} \\
(4.64)\end{array}$ & $\begin{array}{c}0.496^{a} \\
(13.67)\end{array}$ & $\begin{array}{c}0.290^{\mathrm{a}} \\
(13.89)\end{array}$ & $\begin{array}{c}0.491^{\mathrm{a}} \\
(16.48)\end{array}$ \\
\hline $\mathrm{DE}$ & $\begin{array}{l}0.047 \\
(1.40)\end{array}$ & $\begin{array}{l}0.034 \\
(1.13)\end{array}$ & $\begin{array}{l}0.084^{\mathrm{b}} \\
(2.12)\end{array}$ & $\begin{array}{l}0.092^{\mathrm{a}} \\
(8.60)\end{array}$ & $\begin{array}{l}0.178^{\mathrm{a}} \\
(3.55)\end{array}$ & $\begin{array}{l}-0.004 \\
(-0.12)\end{array}$ & $\begin{array}{c}0.002 \\
(0.82)\end{array}$ & $\begin{array}{l}0.011^{\mathrm{a}} \\
(2.91)\end{array}$ & $\begin{array}{c}0.018 \\
(0.28)\end{array}$ & $\begin{array}{c}0.001 \\
(0.05)\end{array}$ \\
\hline PEG & $\begin{array}{l}0.015 \\
(1.42)\end{array}$ & $\begin{array}{l}-0.077 \\
(-0.86) \\
\end{array}$ & $\begin{array}{l}0.021 \\
(0.54)\end{array}$ & $\begin{array}{l}-0.003 \\
(-0.11)\end{array}$ & $\begin{array}{l}-0.027 \\
(-0.84) \\
\end{array}$ & $\begin{array}{l}-0.236^{\mathrm{a}} \\
(-4.37)\end{array}$ & $\begin{array}{l}0.004^{\mathrm{a}} \\
(5.83)\end{array}$ & $\begin{array}{l}-0.002 \\
(-0.72) \\
\end{array}$ & $\begin{array}{l}0.015 \\
(0.54)\end{array}$ & $\begin{array}{l}0.041^{\mathrm{a}} \\
(2.68)\end{array}$ \\
\hline Fed & $\begin{array}{c}0.006 \\
(0.45)\end{array}$ & $\begin{array}{l}0.054 \\
(1.07)\end{array}$ & $\begin{array}{l}0.298^{\mathrm{a}} \\
(5.25)\end{array}$ & $\begin{array}{c}0.619^{\mathrm{a}} \\
(10.93)\end{array}$ & $\begin{array}{l}0.087^{\mathrm{a}} \\
(3.49)\end{array}$ & $\begin{array}{l}0.044 \\
(1.54)\end{array}$ & $\begin{array}{l}0.326^{\mathrm{a}} \\
(4.79)\end{array}$ & $\begin{array}{l}-0.004 \\
(-0.67)\end{array}$ & $\begin{array}{l}0.159^{\mathrm{a}} \\
(4.79)\end{array}$ & $\begin{array}{l}0.008 \\
(0.47)\end{array}$ \\
\hline $\mathrm{RD}$ & $\begin{array}{l}0.361^{\mathrm{a}} \\
(2.58)\end{array}$ & $\begin{array}{l}0.597^{\mathrm{a}} \\
(4.64)\end{array}$ & $\begin{array}{l}0.480^{\mathrm{a}} \\
(3.47)\end{array}$ & $\begin{array}{l}0.374^{\mathrm{a}} \\
(2.59)\end{array}$ & $\begin{array}{l}0.339^{\mathrm{a}} \\
(8.52)\end{array}$ & $\begin{array}{c}0.186 \\
(1.58)\end{array}$ & $\begin{array}{l}0.213^{b} \\
(2.18)\end{array}$ & $\begin{array}{l}0.608^{\mathrm{a}} \\
(4.64)\end{array}$ & $\begin{array}{l}0.384^{\mathrm{a}} \\
(3.86)\end{array}$ & $\begin{array}{l}0.718^{a} \\
(6.38)\end{array}$ \\
\hline Ma-Mi & $\begin{array}{l}-0.136 \\
(-1.13) \\
\end{array}$ & $\begin{array}{l}0.207 \\
(1.48)\end{array}$ & $\begin{array}{l}0.291^{\mathrm{c}} \\
(1.86)\end{array}$ & $\begin{array}{l}0.217^{\mathrm{c}} \\
(1.86)\end{array}$ & $\begin{array}{l}-0.071 \\
(1.03)\end{array}$ & $\begin{array}{c}0.131 \\
(1.02)\end{array}$ & $\begin{array}{l}0.273^{\mathrm{c}} \\
(1.66)\end{array}$ & $\begin{array}{l}0.175^{\mathrm{a}} \\
(4.62)\end{array}$ & $\begin{array}{l}0.133^{b} \\
(2.19)\end{array}$ & $\begin{array}{l}0.607^{\mathrm{a}} \\
(4.21)\end{array}$ \\
\hline AMD & $\begin{array}{l}0.210^{\mathrm{b}} \\
(2.56)\end{array}$ & $\begin{array}{l}0.567^{\mathrm{a}} \\
(5.23)\end{array}$ & $\begin{array}{l}0.356^{\mathrm{a}} \\
(5.41)\end{array}$ & $\begin{array}{l}0.316^{c} \\
(1.79)\end{array}$ & $\begin{array}{l}0.280^{c} \\
(1.67)\end{array}$ & $\begin{array}{l}0.064 \\
(0.35)\end{array}$ & $\begin{array}{l}0.025 \\
(1.32)\end{array}$ & $\begin{array}{l}0.382^{b} \\
(1.98)\end{array}$ & $\begin{array}{l}0.524^{\mathrm{a}} \\
(4.73)\end{array}$ & $\begin{array}{l}0.654^{\mathrm{a}} \\
(4.55)\end{array}$ \\
\hline Sk NP & $\begin{array}{c}-0.087^{b} \\
(2.13)\end{array}$ & $\begin{array}{l}0.085 \\
(0.65)\end{array}$ & $\begin{array}{l}-0.142^{\mathrm{c}} \\
(-1.87)\end{array}$ & $\begin{array}{c}0.146 \\
(1.54)\end{array}$ & $\begin{array}{l}-0.110 \\
(-0.83)\end{array}$ & $\begin{array}{l}0.481^{\mathrm{b}} \\
(1.98)\end{array}$ & $\begin{array}{r}-0.119 \\
(-0.65) \\
\end{array}$ & $\begin{array}{c}0.239 \\
(1.56)\end{array}$ & $\begin{array}{l}-0.258^{\mathrm{b}} \\
(-2.04)\end{array}$ & $\begin{array}{l}-0.261^{b} \\
(-2.48) \\
\end{array}$ \\
\hline Skewness & $\begin{array}{l}0.448^{\mathrm{a}} \\
(3.25)\end{array}$ & $\begin{array}{l}0.792^{\mathrm{a}} \\
(3.86)\end{array}$ & $\begin{array}{l}-0.025 \\
(-1.01)\end{array}$ & $\begin{array}{l}0.508^{a} \\
(5.10)\end{array}$ & $\begin{array}{l}0.680^{b} \\
(2.05)\end{array}$ & $\begin{array}{l}0.810^{\mathrm{a}} \\
(3.54)\end{array}$ & $\begin{array}{l}0.581^{\mathrm{a}} \\
(3.94)\end{array}$ & $\begin{array}{l}0.435^{b} \\
(2.35)\end{array}$ & $\begin{array}{l}0.492^{b} \\
(2.01)\end{array}$ & $\begin{array}{l}0.360^{\mathrm{a}} \\
(2.95)\end{array}$ \\
\hline Kurtosis & $\begin{array}{l}0.520^{\mathrm{a}} \\
(4.15)\end{array}$ & $\begin{array}{l}0.780^{\mathrm{a}} \\
(5.28)\end{array}$ & $\begin{array}{l}0.482^{\mathrm{a}} \\
(4.38)\end{array}$ & $\begin{array}{l}0.709^{a} \\
(3.05)\end{array}$ & $\begin{array}{l}0.478^{b} \\
(2.17)\end{array}$ & $\begin{array}{l}0.912^{\mathrm{a}} \\
(5.36)\end{array}$ & $\begin{array}{l}0.601^{\mathrm{a}} \\
(4.24)\end{array}$ & $\begin{array}{l}0.483^{\mathrm{a}} \\
(3.67)\end{array}$ & $\begin{array}{l}0.396^{\mathrm{a}} \\
(3.06)\end{array}$ & $\begin{array}{l}0.309^{a} \\
(3.01)\end{array}$ \\
\hline
\end{tabular}

Notes: Entries are the AR(1) coefficient (with $t$-statistic) for each predictive variable listed in Table 1. The results are based on a GMM dynamic panel regression for each country. The superscript letters a, b, c refer to $1 \%, 5 \%$, and $10 \%$ statistical significance level respectively. 
Table 4. Panel Regressions: Ratios

\begin{tabular}{|c|c|c|c|c|c|c|c|c|c|c|c|c|}
\hline & \multicolumn{4}{|l|}{ DP } & \multicolumn{4}{|l|}{ PE } & \multicolumn{4}{|l|}{ CAPE } \\
\hline & FE & RD & RD-Adj & \# Obs & FE & RD & RD-Adj & \# Obs & FE & RD & RD-Adj & \# Obs \\
\hline Australia & $\begin{array}{l}0.396^{\mathrm{b}} \\
(2.44)\end{array}$ & $\begin{array}{l}0.129^{\mathrm{b}} \\
(2.09)\end{array}$ & $\begin{array}{l}0.222^{b} \\
(2.40)\end{array}$ & 5853 & $\begin{array}{c}0.091^{\mathrm{b}} \\
(1.98)\end{array}$ & $\begin{array}{l}0.072^{\mathrm{c}} \\
(1.84) \\
\end{array}$ & $\begin{array}{l}0.082^{\mathrm{c}} \\
(1.89)\end{array}$ & 5562 & $\begin{array}{l}0.059^{\mathrm{a}} \\
(2.65)\end{array}$ & $\begin{array}{l}0.044^{\mathrm{a}} \\
(2.71) \\
\end{array}$ & $\begin{array}{l}0.047^{a} \\
(2.94) \\
\end{array}$ & 4152 \\
\hline Canada & $\begin{array}{l}0.093 \\
(0.33) \\
\end{array}$ & $\begin{array}{l}-0.108 \\
(-0.83) \\
\end{array}$ & $\begin{array}{l}0.353^{\mathrm{b}} \\
(2.53)\end{array}$ & 3651 & $\begin{array}{l}0.361^{\mathrm{b}} \\
(2.26)\end{array}$ & $\begin{array}{l}0.342^{b} \\
(2.19)\end{array}$ & $\begin{array}{l}0.403^{\mathrm{b}} \\
(2.34)\end{array}$ & 3218 & $\begin{array}{l}0.990^{\mathrm{a}} \\
(3.07)\end{array}$ & $\begin{array}{l}0.628^{a} \\
(3.04)\end{array}$ & $\begin{array}{l}0.805^{\mathrm{a}} \\
(3.21)\end{array}$ & 2569 \\
\hline France & $\begin{array}{l}0.170^{\mathrm{b}} \\
(2.02)\end{array}$ & $\begin{array}{l}0.031 \\
(0.44)\end{array}$ & $\begin{array}{l}0.171^{\mathrm{b}} \\
(2.37)\end{array}$ & 716 & $\begin{array}{l}0.114^{\mathrm{a}} \\
(4.30)\end{array}$ & $\begin{array}{l}0.064^{\mathrm{a}} \\
(3.59)\end{array}$ & $\begin{array}{l}0.097^{\mathrm{a}} \\
(6.32)\end{array}$ & 709 & $\begin{array}{l}0.139^{a} \\
(4.66)\end{array}$ & $\begin{array}{l}0.048^{a} \\
(3.01)\end{array}$ & $\begin{array}{l}0.093^{\mathrm{a}} \\
(4.62)\end{array}$ & 657 \\
\hline Germany & $\begin{array}{l}0.199^{\mathrm{a}} \\
(2.92)\end{array}$ & $\begin{array}{l}0.066 \\
(1.06)\end{array}$ & $\begin{array}{l}0.220^{\mathrm{a}} \\
(3.47)\end{array}$ & 551 & $\begin{array}{l}0.050^{\mathrm{b}} \\
(2.30)\end{array}$ & $\begin{array}{l}0.035^{\mathrm{c}} \\
(1.90)\end{array}$ & $\begin{array}{l}0.082^{\mathrm{a}} \\
(4.53)\end{array}$ & 548 & $\begin{array}{c}0.059 \\
(1.51)\end{array}$ & $\begin{array}{l}0.012 \\
(0.42)\end{array}$ & $\begin{array}{l}0.061 \\
(1.37)\end{array}$ & 509 \\
\hline $\begin{array}{l}\text { Hong } \\
\text { Kong }\end{array}$ & $\begin{array}{l}0.616^{\mathrm{a}} \\
(3.13)\end{array}$ & $\begin{array}{l}0.264^{\mathrm{a}} \\
(2.88)\end{array}$ & $\begin{array}{l}0.370^{a} \\
(4.78)\end{array}$ & 754 & $\begin{array}{l}0.149^{b} \\
(2.32)\end{array}$ & $\begin{array}{l}0.108^{b} \\
(2.41)\end{array}$ & $\begin{array}{l}0.123^{a} \\
(3.25)\end{array}$ & 735 & $\begin{array}{l}0.185^{\mathrm{a}} \\
(3.22)\end{array}$ & $\begin{array}{l}0.099^{\mathrm{a}} \\
(3.50)\end{array}$ & $\begin{array}{l}0.189^{a} \\
(7.33)\end{array}$ & 616 \\
\hline Italy & $\begin{array}{l}0.089^{\mathrm{a}} \\
(2.59)\end{array}$ & $\begin{array}{l}0.075^{\mathrm{b}} \\
(2.20)\end{array}$ & $\begin{array}{l}0.110^{\mathrm{a}} \\
(3.24)\end{array}$ & 4264 & $\begin{array}{l}0.118^{\mathrm{b}} \\
(2.33)\end{array}$ & $\begin{array}{l}0.078 \\
(1.51)\end{array}$ & $\begin{array}{l}0.147^{b} \\
(2.36)\end{array}$ & 4138 & $\begin{array}{l}0.049 \\
(0.65)\end{array}$ & $\begin{array}{l}-0.020 \\
(-0.20)\end{array}$ & $\begin{array}{l}0.052 \\
(0.46)\end{array}$ & 3365 \\
\hline Japan & $\begin{array}{l}0.066^{\mathrm{a}} \\
(5.30) \\
\end{array}$ & $\begin{array}{l}0.034^{\mathrm{a}} \\
(4.49) \\
\end{array}$ & $\begin{array}{l}0.058^{\mathrm{a}} \\
(5.38) \\
\end{array}$ & 4159 & $\begin{array}{l}0.116^{\mathrm{a}} \\
(8.46)\end{array}$ & $\begin{array}{l}0.076^{\mathrm{a}} \\
(6.97)\end{array}$ & $\begin{array}{l}0.127^{\mathrm{a}} \\
(9.10)\end{array}$ & 4142 & $\begin{array}{l}0.160^{\mathrm{a}} \\
(7.13)\end{array}$ & $\begin{array}{l}0.059^{\mathrm{a}} \\
(4.07)\end{array}$ & $\begin{array}{l}0.137^{a} \\
(6.52)\end{array}$ & 4029 \\
\hline $\begin{array}{l}\text { South } \\
\text { Korea }\end{array}$ & $\begin{array}{l}0.038^{\mathrm{a}} \\
(7.27)\end{array}$ & $\begin{array}{l}0.027^{\mathrm{a}} \\
(6.82)\end{array}$ & $\begin{array}{l}0.032^{\mathrm{a}} \\
(7.90)\end{array}$ & 3080 & $\begin{array}{l}0.019^{b} \\
(2.45)\end{array}$ & $\begin{array}{l}0.009 \\
(1.64)\end{array}$ & $\begin{array}{l}0.009^{c} \\
(1.66)\end{array}$ & 3013 & $\begin{array}{l}0.070^{\mathrm{b}} \\
(2.56)\end{array}$ & $\begin{array}{l}0.019 \\
(1.30)\end{array}$ & $\begin{array}{l}0.021 \\
(1.35)\end{array}$ & 2643 \\
\hline UK & $\begin{array}{l}0.139^{a} \\
(4.22)\end{array}$ & $\begin{array}{l}0.096^{\mathrm{a}} \\
(4.29)\end{array}$ & $\begin{array}{l}0.107^{a} \\
(4.62)\end{array}$ & 9179 & $\begin{array}{l}0.378^{\mathrm{b}} \\
(2.47)\end{array}$ & $\begin{array}{l}0.227^{b} \\
(2.17)\end{array}$ & $\begin{array}{l}0.260^{\mathrm{b}} \\
(2.31)\end{array}$ & 8928 & $\begin{array}{l}0.239^{c} \\
(1.81)\end{array}$ & $\begin{array}{l}0.123^{c} \\
(1.65)\end{array}$ & $\begin{array}{l}0.141^{\mathrm{c}} \\
(1.77)\end{array}$ & 7751 \\
\hline US & $\begin{array}{l}0.177^{a} \\
(6.23)\end{array}$ & $\begin{array}{l}0.039^{b} \\
(2.01)\end{array}$ & $\begin{array}{l}0.063^{\mathrm{b}} \\
(1.98)\end{array}$ & 8722 & $\begin{array}{l}0.059^{a} \\
(2.68)\end{array}$ & $\begin{array}{l}0.034^{\mathrm{b}} \\
(2.22)\end{array}$ & $\begin{array}{l}0.050^{\mathrm{a}} \\
(2.71)\end{array}$ & 8619 & $\begin{array}{l}0.083^{\mathrm{b}} \\
(2.18)\end{array}$ & $\begin{array}{l}0.031^{\mathrm{a}} \\
(2.88)\end{array}$ & $\begin{array}{l}0.064^{b} \\
(2.24)\end{array}$ & 7894 \\
\hline
\end{tabular}

Notes: the entries are coefficient values (and $t$-statistics) from a pool regression as given by equation (1) for each country. The standard errors are clustered at the firm-level. The predictor variables are DP (dividend-price ratio), PE (price-earnings ratio) and CAPE (cyclically adjusted $\mathrm{PE}$ ratio). In reporting the results, these later two are inverted for the sake of consistency in understanding the coefficient signs. The estimation methods are the fixed effects (FE), the recursive de-meaned (RD) and orthogonalised and then de-meaned (RD-Adj) approaches respectively. The superscript letters a, b, c refer to $1 \%, 5 \%$, and $10 \%$ statistical significance level respectively. 
Table 5. Panel Regressions: Further Ratios

\begin{tabular}{|c|c|c|c|c|c|c|c|c|c|c|c|c|}
\hline & \multicolumn{4}{|l|}{ DE } & \multicolumn{4}{|l|}{ PEG } & \multicolumn{4}{|l|}{ Fed } \\
\hline & $\mathrm{FE}$ & RD & RD-Adj & \# Obs & FE & $\mathrm{RD}$ & RD-Adj & \# Obs & FE & RD & RD-Adj & \# Obs \\
\hline Australia & $\begin{array}{l}-0.004 \\
(-1.49) \\
\end{array}$ & $\begin{array}{c}-0.004^{b} \\
(-2.31)\end{array}$ & $\begin{array}{l}-0.005^{\mathrm{b}} \\
(-2.53)\end{array}$ & 3931 & $\begin{array}{l}-0.002 \\
(-0.40)\end{array}$ & $\begin{array}{l}-0.001 \\
(-0.47) \\
\end{array}$ & $\begin{array}{l}-0.001 \\
(-0.51)\end{array}$ & 3347 & $\begin{array}{l}0.059^{\mathrm{a}} \\
(2.62)\end{array}$ & $\begin{array}{l}0.043^{\mathrm{a}} \\
(3.52)\end{array}$ & $\begin{array}{l}0.046^{\mathrm{b}} \\
(2.44)\end{array}$ & 5562 \\
\hline Canada & $\begin{array}{l}-0.001 \\
(-0.30) \\
\end{array}$ & $\begin{array}{l}-0.004 \\
(-1.24) \\
\end{array}$ & $\begin{array}{l}-0.002 \\
(-0.87) \\
\end{array}$ & 2586 & $\begin{array}{l}-0.001 \\
(-0.02) \\
\end{array}$ & $\begin{array}{l}0.001 \\
(0.18) \\
\end{array}$ & $\begin{array}{l}0.001 \\
(0.19)\end{array}$ & 2402 & $\begin{array}{l}0.014^{\mathrm{a}} \\
(3.38)\end{array}$ & $\begin{array}{l}0.013^{\mathrm{a}} \\
(3.17)\end{array}$ & $\begin{array}{l}0.016^{\mathrm{a}} \\
(3.76)\end{array}$ & 3218 \\
\hline France & $\begin{array}{l}-0.005 \\
(-1.05) \\
\end{array}$ & $\begin{array}{l}-0.007 \\
(-0.99) \\
\end{array}$ & $\begin{array}{l}-0.006 \\
(-0.87) \\
\end{array}$ & 637 & $\begin{array}{c}0.006 \\
(-0.32) \\
\end{array}$ & $\begin{array}{l}0.001 \\
(0.02)\end{array}$ & $\begin{array}{l}-0.001 \\
(-1.48) \\
\end{array}$ & 581 & $\begin{array}{l}0.045^{\mathrm{a}} \\
(4.77)\end{array}$ & $\begin{array}{l}0.025^{\mathrm{a}} \\
(3.98)\end{array}$ & $\begin{array}{l}0.039^{a} \\
(6.91)\end{array}$ & 709 \\
\hline Germany & $\begin{array}{l}-0.010 \\
(-0.93)\end{array}$ & $\begin{array}{l}-0.015 \\
(-1.63)\end{array}$ & $\begin{array}{l}-0.015^{\mathrm{c}} \\
(-1.66)\end{array}$ & 505 & $\begin{array}{l}0.003^{\mathrm{b}} \\
(2.49)\end{array}$ & $\begin{array}{l}0.003^{\mathrm{a}} \\
(2.75)\end{array}$ & $\begin{array}{l}0.003^{\mathrm{a}} \\
(3.19)\end{array}$ & 462 & $\begin{array}{l}0.021^{\mathrm{a}} \\
(4.65)\end{array}$ & $\begin{array}{l}0.011^{\mathrm{a}} \\
(2.62)\end{array}$ & $\begin{array}{l}0.014^{\mathrm{a}} \\
(3.40)\end{array}$ & 548 \\
\hline $\begin{array}{l}\text { Hong } \\
\text { Kong }\end{array}$ & $\begin{array}{l}-0.015 \\
(-0.23)\end{array}$ & $\begin{array}{l}-0.033 \\
(-0.62)\end{array}$ & $\begin{array}{l}-0.048 \\
(-0.87)\end{array}$ & 710 & $\begin{array}{l}-0.005^{\mathrm{a}} \\
(-2.68)\end{array}$ & $\begin{array}{l}-0.003 \\
(-1.60)\end{array}$ & $\begin{array}{l}-0.003 \\
(-1.57)\end{array}$ & 620 & $\begin{array}{l}0.012^{\mathrm{a}} \\
(5.29)\end{array}$ & $\begin{array}{l}0.018^{\mathrm{a}} \\
(5.58)\end{array}$ & $\begin{array}{l}0.014^{\mathrm{a}} \\
(6.37)\end{array}$ & 636 \\
\hline Italy & $\begin{array}{l}0.003 \\
(0.50)\end{array}$ & $\begin{array}{l}-0.002 \\
(-0.42)\end{array}$ & $\begin{array}{l}-0.002 \\
(-0.43)\end{array}$ & 2842 & $\begin{array}{l}-0.001^{\mathrm{a}} \\
(-5.12)\end{array}$ & $\begin{array}{l}-0.001^{\mathrm{a}} \\
(-3.73)\end{array}$ & $\begin{array}{l}-0.001^{a} \\
(-3.63)\end{array}$ & 2361 & $\begin{array}{l}0.008^{\mathrm{a}} \\
(3.30)\end{array}$ & $\begin{array}{l}0.005^{\mathrm{b}} \\
(2.04)\end{array}$ & $\begin{array}{l}0.008^{\mathrm{a}} \\
(2.60)\end{array}$ & 4138 \\
\hline Japan & $\begin{array}{l}-0.003^{\mathrm{a}} \\
(-4.81) \\
\end{array}$ & $\begin{array}{l}-0.002^{\mathrm{a}} \\
(-4.52)\end{array}$ & $\begin{array}{l}-0.002^{\mathrm{a}} \\
(-4.39) \\
\end{array}$ & 3423 & $\begin{array}{l}-0.002^{a} \\
(-9.00)\end{array}$ & $\begin{array}{l}-0.002^{\mathrm{a}} \\
(-8.36) \\
\end{array}$ & $\begin{array}{l}-0.002^{\mathrm{a}} \\
(-8.33)\end{array}$ & 3388 & $\begin{array}{l}0.016^{\mathrm{a}} \\
(7.51) \\
\end{array}$ & $\begin{array}{l}0.011^{\mathrm{a}} \\
(7.24) \\
\end{array}$ & $\begin{array}{l}0.012^{\mathrm{a}} \\
(7.45) \\
\end{array}$ & 4142 \\
\hline $\begin{array}{l}\text { South } \\
\text { Korea }\end{array}$ & $\begin{array}{l}0.015^{\mathrm{b}} \\
(2.04)\end{array}$ & $\begin{array}{l}0.010 \\
(1.49)\end{array}$ & $\begin{array}{l}0.015^{\mathrm{b}} \\
(1.99)\end{array}$ & 2585 & $\begin{array}{l}0.003^{c} \\
(1.69)\end{array}$ & $\begin{array}{l}0.002^{c} \\
(1.70)\end{array}$ & $\begin{array}{l}0.003^{\mathrm{b}} \\
(2.53)\end{array}$ & 2462 & $\begin{array}{l}0.010^{\mathrm{a}} \\
(2.82)\end{array}$ & $\begin{array}{l}0.053 \\
(1.30)\end{array}$ & $\begin{array}{l}0.066 \\
(1.48)\end{array}$ & 2321 \\
\hline UK & $\begin{array}{l}-0.001 \\
(-0.59)\end{array}$ & $\begin{array}{l}-0.001 \\
(-1.14)\end{array}$ & $\begin{array}{l}-0.001 \\
(-1.04)\end{array}$ & 8157 & $\begin{array}{l}0.001 \\
(0.94)\end{array}$ & $\begin{array}{l}0.001 \\
(1.45)\end{array}$ & $\begin{array}{l}0.001 \\
(1.52)\end{array}$ & 7788 & $\begin{array}{l}0.013^{\mathrm{a}} \\
(2.71)\end{array}$ & $\begin{array}{l}0.008^{\mathrm{b}} \\
(2.53)\end{array}$ & $\begin{array}{l}0.009^{a} \\
(2.60)\end{array}$ & 8928 \\
\hline US & $\begin{array}{l}-0.002^{\mathrm{c}} \\
(-1.72)\end{array}$ & $\begin{array}{l}-0.002^{b} \\
(-1.98)\end{array}$ & $\begin{array}{l}-0.003^{b} \\
(-2.14)\end{array}$ & 7857 & $\begin{array}{l}0.001 \\
(0.18)\end{array}$ & $\begin{array}{l}0.001 \\
(0.11)\end{array}$ & $\begin{array}{l}0.001 \\
(0.06) \\
\end{array}$ & 7630 & $\begin{array}{l}0.017^{\mathrm{b}} \\
(2.41)\end{array}$ & $\begin{array}{l}0.010^{\mathrm{b}} \\
(2.02)\end{array}$ & $\begin{array}{l}0.014^{\mathrm{b}} \\
(2.27)\end{array}$ & 8619 \\
\hline
\end{tabular}

Notes: the entries are coefficient values (and $t$-statistics) from a pool model as given by equation (1) for each country. The standard errors are clustered at the firm-level. The predictor variables are DE (dividend-earnings ratio), PEG (PE ratio divided by earnings growth) and Fed (equity yield divided by the 10-year bond yield). The estimation methods are the fixed effects (FE), the recursive de-meaned (RD) and orthogonalised and then de-meaned (RD-Adj) approaches respectively. The superscript letters a, b, c refer to 1\%, 5\%, and $10 \%$ statistical significance level respectively. 
Table 6. Panel Regressions: Dispersion

\begin{tabular}{|c|c|c|c|c|c|c|c|c|c|c|c|c|}
\hline & \multicolumn{4}{|l|}{$\mathrm{RD}$} & \multicolumn{4}{|l|}{ Max-Min } & \multicolumn{4}{|c|}{ Abs Median Deviation } \\
\hline & FE & RD & RD-Adj & \# Obs & $\mathrm{FE}$ & $\mathrm{RD}$ & RD-Adj & \# Obs & $\mathrm{FE}$ & $\mathrm{RD}$ & RD-Adj & \# Obs \\
\hline Australia & $\begin{array}{c}0.969^{\mathrm{a}} \\
(9.98)\end{array}$ & $\begin{array}{c}0.803^{\mathrm{a}} \\
(8.77)\end{array}$ & $\begin{array}{c}1.115^{\mathrm{a}} \\
(12.34)\end{array}$ & 6076 & $\begin{array}{c}0.115^{\mathrm{a}} \\
(14.97)\end{array}$ & $\begin{array}{c}0.107^{\mathrm{a}} \\
(14.73)\end{array}$ & $\begin{array}{c}0.095^{\mathrm{a}} \\
(13.15)\end{array}$ & 6076 & $\begin{array}{c}2.088^{a} \\
(14.20)\end{array}$ & $\begin{array}{c}1.756^{\mathrm{a}} \\
(12.64)\end{array}$ & $\begin{array}{c}2.231^{\mathrm{a}} \\
(16.69)\end{array}$ & 6076 \\
\hline Canada & $\begin{array}{c}0.910^{\mathrm{a}} \\
(11.98)\end{array}$ & $\begin{array}{l}0.702^{\mathrm{a}} \\
(9.98)\end{array}$ & $\begin{array}{c}0.728^{a} \\
(10.35)\end{array}$ & 3676 & $\begin{array}{l}0.037^{\mathrm{a}} \\
(5.33)\end{array}$ & $\begin{array}{l}0.034^{\mathrm{a}} \\
(5.19)\end{array}$ & $\begin{array}{l}0.033^{\mathrm{a}} \\
(4.95)\end{array}$ & 3676 & $\begin{array}{l}0.557^{\mathrm{a}} \\
(3.93)\end{array}$ & $\begin{array}{l}0.229^{c} \\
(1.72)\end{array}$ & $\begin{array}{l}0.799^{\mathrm{a}} \\
(6.03)\end{array}$ & 3676 \\
\hline France & $\begin{array}{l}0.674^{\mathrm{a}} \\
(3.07)\end{array}$ & $\begin{array}{l}0.666^{a} \\
(3.14)\end{array}$ & $\begin{array}{l}0.996^{\mathrm{a}} \\
(4.72)\end{array}$ & 697 & $\begin{array}{l}0.031 \\
(0.84)\end{array}$ & $\begin{array}{l}0.052 \\
(1.46)\end{array}$ & $\begin{array}{l}0.069^{b} \\
(1.97)\end{array}$ & 697 & $\begin{array}{l}1.082^{\mathrm{a}} \\
(4.11)\end{array}$ & $\begin{array}{l}0.795^{\mathrm{a}} \\
(3.13)\end{array}$ & $\begin{array}{l}1.156^{\mathrm{a}} \\
(4.61)\end{array}$ & 697 \\
\hline Germany & $\begin{array}{l}0.099 \\
(0.46)\end{array}$ & $\begin{array}{l}-0.099 \\
(-0.47)\end{array}$ & $\begin{array}{l}0.621^{\mathrm{a}} \\
(2.97)\end{array}$ & 539 & $\begin{array}{l}0.174^{\mathrm{a}} \\
(3.54)\end{array}$ & $\begin{array}{l}0.119^{b} \\
(2.52)\end{array}$ & $\begin{array}{l}0.226^{\mathrm{a}} \\
(4.81)\end{array}$ & 539 & $\begin{array}{l}-0.924^{\mathrm{a}} \\
(-3.91)\end{array}$ & $\begin{array}{l}-1.012^{\mathrm{a}} \\
(-4.32)\end{array}$ & $\begin{array}{l}-0.497^{b} \\
(-2.11)\end{array}$ & 539 \\
\hline $\begin{array}{l}\text { Hong } \\
\text { Kong }\end{array}$ & $\begin{array}{l}0.316 \\
(1.63)\end{array}$ & $\begin{array}{l}0.087 \\
(0.49)\end{array}$ & $\begin{array}{l}0.074 \\
(0.42)\end{array}$ & 756 & $\begin{array}{l}0.074^{\mathrm{a}} \\
(2.67)\end{array}$ & $\begin{array}{l}0.045^{\mathrm{c}} \\
(1.73)\end{array}$ & $\begin{array}{l}0.049^{c} \\
(1.86)\end{array}$ & 756 & $\begin{array}{l}0.685^{\mathrm{a}} \\
(2.99)\end{array}$ & $\begin{array}{l}0.436^{\mathrm{b}} \\
(2.07)\end{array}$ & $\begin{array}{l}0.455^{\mathrm{b}} \\
(2.16)\end{array}$ & 756 \\
\hline Italy & $\begin{array}{c}0.964^{\mathrm{a}} \\
(11.21)\end{array}$ & $\begin{array}{l}0.289^{\mathrm{a}} \\
(3.76)\end{array}$ & $\begin{array}{c}0.885^{\mathrm{a}} \\
(11.52)\end{array}$ & 4351 & $\begin{array}{l}0.045^{\mathrm{a}} \\
(9.94)\end{array}$ & $\begin{array}{l}0.004 \\
(0.98)\end{array}$ & $\begin{array}{l}0.021^{\mathrm{a}} \\
(5.35)\end{array}$ & 4351 & $\begin{array}{l}0.864^{\mathrm{a}} \\
(5.87)\end{array}$ & $\begin{array}{l}0.562^{\mathrm{a}} \\
(3.96)\end{array}$ & $\begin{array}{l}0.743^{\mathrm{a}} \\
(5.26)\end{array}$ & 4351 \\
\hline Japan & $\begin{array}{l}0.169^{\mathrm{a}} \\
(3.02)\end{array}$ & $\begin{array}{l}0.161^{\mathrm{a}} \\
(2.98)\end{array}$ & $\begin{array}{l}0.192^{\mathrm{a}} \\
(3.55)\end{array}$ & 3994 & $\begin{array}{l}0.034^{\mathrm{a}} \\
(4.42)\end{array}$ & $\begin{array}{l}0.021^{\mathrm{a}} \\
(2.82)\end{array}$ & $\begin{array}{l}0.026^{\mathrm{a}} \\
(3.44)\end{array}$ & 394 & $\begin{array}{l}0.511^{\mathrm{a}} \\
(6.99)\end{array}$ & $\begin{array}{l}0.434^{\mathrm{a}} \\
(6.15)\end{array}$ & $\begin{array}{l}0.445^{\mathrm{a}} \\
(6.30)\end{array}$ & 3994 \\
\hline $\begin{array}{l}\text { South } \\
\text { Korea }\end{array}$ & $\begin{array}{l}-0.107 \\
(-1.04)\end{array}$ & $\begin{array}{l}-0.396^{\mathrm{a}} \\
(-4.03)\end{array}$ & $\begin{array}{l}-0.403^{\mathrm{a}} \\
(-3.95)\end{array}$ & 3060 & $\begin{array}{l}-0.018 \\
(-1.42)\end{array}$ & $\begin{array}{l}-0.052^{\mathrm{a}} \\
(-4.15)\end{array}$ & $\begin{array}{l}-0.051^{\mathrm{a}} \\
(-3.90)\end{array}$ & 3060 & $\begin{array}{l}-0.253^{b} \\
(-1.99)\end{array}$ & $\begin{array}{l}-0.551^{\mathrm{a}} \\
(-4.50)\end{array}$ & $\begin{array}{l}-0.527^{a} \\
(-4.14)\end{array}$ & 3060 \\
\hline UK & $\begin{array}{c}0.659^{\mathrm{a}} \\
(14.41)\end{array}$ & $\begin{array}{l}0.667^{\mathrm{a}} \\
(15.06)\end{array}$ & $\begin{array}{c}0.909^{\mathrm{a}} \\
(20.88)\end{array}$ & 9146 & $\begin{array}{c}0.087^{\mathrm{a}} \\
(15.51)\end{array}$ & $\begin{array}{c}0.087^{a} \\
(16.12)\end{array}$ & $\begin{array}{c}0.083^{\mathrm{a}} \\
(15.54)\end{array}$ & 9146 & $\begin{array}{l}0.195^{\mathrm{b}} \\
(2.30)\end{array}$ & $\begin{array}{l}0.210^{\mathrm{b}} \\
(2.57)\end{array}$ & $\begin{array}{l}0.645^{\mathrm{a}} \\
(7.91)\end{array}$ & 9146 \\
\hline US & $\begin{array}{l}-0.228^{a} \\
(-7.14)\end{array}$ & $\begin{array}{l}-0.213^{\mathrm{a}} \\
(-6.67) \\
\end{array}$ & $\begin{array}{l}0.098^{\mathrm{a}} \\
(3.07)\end{array}$ & 8499 & $\begin{array}{c}-0.047^{\mathrm{a}} \\
(-14.84) \\
\end{array}$ & $\begin{array}{l}-0.044^{\mathrm{a}} \\
(-14.35)\end{array}$ & $\begin{array}{l}-0.021^{a} \\
(-6.69) \\
\end{array}$ & 8499 & $\begin{array}{c}-0.710^{a} \\
(-10.41) \\
\end{array}$ & $\begin{array}{l}-0.676^{\mathrm{a}} \\
(-9.91) \\
\end{array}$ & $\begin{array}{l}0.012 \\
(0.17) \\
\end{array}$ & 8499 \\
\hline
\end{tabular}

Notes: the entries are coefficient values (and $t$-statistics) from a pool model as given by equation (1) for each country. The standard errors are clustered at the firm-level. The predictor variables are RD (cross-sectional returns dispersion), Max-Min (the cross-sectional difference between the maximum and minimum returns) and Abs Median Deviation (absolute median deviation). The estimation methods are the fixed effects (FE), the recursive de-meaned (RD) and orthogonalised and then de-meaned (RD-Adj) approaches respectively. The superscript letters a, b, $c$ refer to $1 \%, 5 \%$, and $10 \%$ statistical significance level respectively. 
Table 7. Panel Regressions: Skew / Kurt

\begin{tabular}{|c|c|c|c|c|c|c|c|c|c|c|c|c|}
\hline & \multicolumn{4}{|l|}{ Skew NP } & \multicolumn{4}{|l|}{ Skewness } & \multicolumn{4}{|l|}{ Kurtosis } \\
\hline & FE & RD & RD-Adj & \# Obs & FE & RD & RD-Adj & \# Obs & $\mathrm{FE}$ & RD & RD-Adj & \# Obs \\
\hline Australia & $\begin{array}{l}-0.892^{\mathrm{a}} \\
(-13.88)\end{array}$ & $\begin{array}{c}-0.766^{\mathrm{a}} \\
(-12.50)\end{array}$ & $\begin{array}{l}-0.692^{\mathrm{a}} \\
(-11.26)\end{array}$ & 6076 & $\begin{array}{l}-0.173^{\mathrm{a}} \\
(-13.33)\end{array}$ & $\begin{array}{c}-0.146^{\mathrm{a}} \\
(-12.35)\end{array}$ & $\begin{array}{l}-0.179^{\mathrm{a}} \\
(-15.23)\end{array}$ & 6076 & $\begin{array}{c}0.005^{\mathrm{c}} \\
(1.82)\end{array}$ & $\begin{array}{l}0.003 \\
(1.15)\end{array}$ & $\begin{array}{l}0.003 \\
(1.32)\end{array}$ & 6076 \\
\hline Canada & $\begin{array}{l}0.110^{\mathrm{b}} \\
(2.06)\end{array}$ & $\begin{array}{l}0.170^{\mathrm{a}} \\
(3.31) \\
\end{array}$ & $\begin{array}{l}0.103^{b} \\
(2.02)\end{array}$ & 3676 & $\begin{array}{l}-0.029^{a} \\
(-3.46)\end{array}$ & $\begin{array}{l}-0.018^{b} \\
(-2.16) \\
\end{array}$ & $\begin{array}{l}-0.025^{\mathrm{a}} \\
(-6.19) \\
\end{array}$ & 3676 & $\begin{array}{l}-0.003^{c} \\
(-1.72)\end{array}$ & $\begin{array}{l}-0.001 \\
(-0.54) \\
\end{array}$ & $\begin{array}{l}-0.005^{\mathrm{a}} \\
(-3.41) \\
\end{array}$ & 3676 \\
\hline France & $\begin{array}{l}0.026 \\
(0.35) \\
\end{array}$ & $\begin{array}{l}0.095 \\
(1.32) \\
\end{array}$ & $\begin{array}{l}0.099 \\
(1.38)\end{array}$ & 697 & $\begin{array}{l}-0.217^{a} \\
(-7.70)\end{array}$ & $\begin{array}{l}-0.186^{\mathrm{a}} \\
(-6.83) \\
\end{array}$ & $\begin{array}{l}-0.182^{a} \\
(-6.69) \\
\end{array}$ & 697 & $\begin{array}{l}-0.085^{\mathrm{a}} \\
(-9.40)\end{array}$ & $\begin{array}{l}-0.069^{a} \\
(-7.97) \\
\end{array}$ & $\begin{array}{l}-0.062^{a} \\
(-7.15) \\
\end{array}$ & 697 \\
\hline Germany & $\begin{array}{l}-0.020 \\
(-0.27)\end{array}$ & $\begin{array}{l}0.057 \\
(0.81)\end{array}$ & $\begin{array}{l}-0.011 \\
(-1.53)\end{array}$ & 539 & $\begin{array}{l}-0.054^{\mathrm{a}} \\
(-2.66)\end{array}$ & $\begin{array}{l}-0.030^{\mathrm{c}} \\
(-1.78)\end{array}$ & $\begin{array}{l}-0.060^{\mathrm{a}} \\
(-3.59)\end{array}$ & 539 & $\begin{array}{l}0.035^{\mathrm{a}} \\
(3.16)\end{array}$ & $\begin{array}{l}0.024^{b} \\
(2.33)\end{array}$ & $\begin{array}{l}0.038^{a} \\
(3.65)\end{array}$ & 539 \\
\hline $\begin{array}{l}\text { Hong } \\
\text { Kong }\end{array}$ & $\begin{array}{l}-0.154 \\
(-1.51) \\
\end{array}$ & $\begin{array}{l}-0.158 \\
(-1.63) \\
\end{array}$ & $\begin{array}{l}-0.177^{c} \\
(-1.86) \\
\end{array}$ & 756 & $\begin{array}{l}-0.064^{\mathrm{a}} \\
(-3.75)\end{array}$ & $\begin{array}{l}-0.080^{\mathrm{a}} \\
(-5.14) \\
\end{array}$ & $\begin{array}{l}-0.121^{\mathrm{a}} \\
(-8.05)\end{array}$ & 756 & $\begin{array}{l}0.016^{c} \\
(1.94)\end{array}$ & $\begin{array}{l}0.005 \\
(0.67) \\
\end{array}$ & $\begin{array}{l}-0.012 \\
(-1.60) \\
\end{array}$ & 756 \\
\hline Italy & $\begin{array}{l}0.178^{\mathrm{a}} \\
(3.69)\end{array}$ & $\begin{array}{l}0.297^{\mathrm{a}} \\
(6.27)\end{array}$ & $\begin{array}{l}-0.256^{\mathrm{a}} \\
(-5.49)\end{array}$ & 4351 & $\begin{array}{l}0.024^{\mathrm{a}} \\
(2.75)\end{array}$ & $\begin{array}{l}0.042^{\mathrm{a}} \\
(4.95)\end{array}$ & $\begin{array}{l}-0.080^{\mathrm{a}} \\
(-9.61)\end{array}$ & 4351 & $\begin{array}{l}0.012^{\mathrm{a}} \\
(6.16)\end{array}$ & $\begin{array}{l}-0.014^{\mathrm{a}} \\
(-8.96)\end{array}$ & $\begin{array}{l}-0.014^{\mathrm{a}} \\
(-9.02)\end{array}$ & 4351 \\
\hline Japan & $\begin{array}{l}0.298^{a} \\
(4.20)\end{array}$ & $\begin{array}{l}0.378^{a} \\
(5.44)\end{array}$ & $\begin{array}{l}0.554^{\mathrm{a}} \\
(7.99)\end{array}$ & 3994 & $\begin{array}{l}-0.059^{\mathrm{a}} \\
(-8.04)\end{array}$ & $\begin{array}{l}-0.032^{\mathrm{a}} \\
(-4.63)\end{array}$ & $\begin{array}{c}-0.057^{a} \\
(-8.09)\end{array}$ & 3994 & $\begin{array}{l}0.006^{\mathrm{a}} \\
(3.22)\end{array}$ & $\begin{array}{l}0.008^{a} \\
(4.43)\end{array}$ & $\begin{array}{l}0.004^{\mathrm{b}} \\
(2.37)\end{array}$ & 3994 \\
\hline $\begin{array}{l}\text { South } \\
\text { Korea }\end{array}$ & $\begin{array}{l}-1.231^{\mathrm{a}} \\
(-9.83)\end{array}$ & $\begin{array}{l}-1.035^{\mathrm{a}} \\
(-8.54)\end{array}$ & $\begin{array}{l}-1.663^{\mathrm{a}} \\
(-13.36)\end{array}$ & 3060 & $\begin{array}{l}-0.440^{\mathrm{a}} \\
(-21.86)\end{array}$ & $\begin{array}{c}-0.413^{\mathrm{a}} \\
(-21.28)\end{array}$ & $\begin{array}{c}-0.380^{\mathrm{a}} \\
(-18.94)\end{array}$ & 3060 & $\begin{array}{c}-0.056^{\mathrm{a}} \\
(-11.66)\end{array}$ & $\begin{array}{c}-0.057^{\mathrm{a}} \\
(-12.34)\end{array}$ & $\begin{array}{l}-0.033^{\mathrm{a}} \\
(-6.90)\end{array}$ & 3060 \\
\hline UK & $\begin{array}{c}-0.141^{\mathrm{a}} \\
(-3.50)\end{array}$ & $\begin{array}{l}-0.139^{\mathrm{a}} \\
(-3.56)\end{array}$ & $\begin{array}{l}0.229^{\mathrm{a}} \\
(5.87)\end{array}$ & 9146 & $\begin{array}{c}-0.127 \\
(-20.80)\end{array}$ & $\begin{array}{l}-0.124^{\mathrm{a}} \\
(-21.29)\end{array}$ & $\begin{array}{l}-0.124^{\mathrm{a}} \\
(-21.44)\end{array}$ & 9146 & $\begin{array}{l}0.007^{\mathrm{a}} \\
(5.38)\end{array}$ & $\begin{array}{l}0.008^{\mathrm{a}} \\
(5.78)\end{array}$ & $\begin{array}{l}0.007^{\mathrm{a}} \\
(5.21)\end{array}$ & 9146 \\
\hline US & $\begin{array}{l}-0.402^{a} \\
(-10.01)\end{array}$ & $\begin{array}{l}-0.300^{\mathrm{a}} \\
(-7.72)\end{array}$ & $\begin{array}{l}-0.022 \\
(-0.58)\end{array}$ & 8499 & $\begin{array}{l}-0.075^{a} \\
(-12.95)\end{array}$ & $\begin{array}{l}-0.048^{a} \\
(-8.96)\end{array}$ & $\begin{array}{l}-0.077^{a} \\
(-14.44)\end{array}$ & 8499 & $\begin{array}{c}0.044^{\mathrm{a}} \\
(17.64)\end{array}$ & $\begin{array}{c}0.036^{\mathrm{a}} \\
(15.67)\end{array}$ & $\begin{array}{c}0.036^{\mathrm{a}} \\
(15.66)\end{array}$ & 8499 \\
\hline
\end{tabular}

Notes: the entries are coefficient values (and $t$-statistics) from a pool model as given by equation (1) for each country. The standard errors are clustered at the firm-level. The predictor variables are Skew NP (non-parametric skewness), Skewness (Pearson's measure) and Kurtosis. The estimation methods are the fixed effects (FE), the recursive de-meaned (RD) and orthogonalised and then de-meaned (RD-Adj) approaches respectively. The superscript letters a, b, c refer to $1 \%, 5 \%$, and $10 \%$ statistical significance level respectively. 
Table 8. Cross-Section Variation - The Percentage of Positive Values

\begin{tabular}{|c|c|c|c|c|c|c|c|c|c|c|c|}
\hline & Aus & Can & Fra & Ger & $\mathrm{HK}$ & Ity & Jpy & $\mathrm{SK}$ & UK & US & Ave. \\
\hline $\mathrm{DP}$ & 62 & 66 & 85 & 87 & 82 & 63 & 92 & 80 & 84 & 76 & 78 \\
\hline EP & 65 & 60 & 75 & 67 & 90 & 57 & 79 & 77 & 81 & 75 & 73 \\
\hline CAPE & 75 & 76 & 85 & 83 & 90 & 70 & 91 & 90 & 90 & 85 & 84 \\
\hline $\mathrm{DE}$ & 43 & 43 & 50 & 67 & 48 & 52 & 46 & 54 & 34 & 47 & 48 \\
\hline PEG & 56 & 50 & 43 & 37 & 56 & 46 & 50 & 48 & 49 & 56 & 49 \\
\hline Fed & 69 & 61 & 83 & 83 & 76 & 58 & 88 & 68 & 85 & 74 & 75 \\
\hline DISP & 68 & 86 & 73 & 43 & 72 & 80 & 68 & 47 & 74 & 35 & 65 \\
\hline Ma-Mi & 78 & 63 & 50 & 80 & 72 & 75 & 73 & 48 & 74 & 21 & 63 \\
\hline AMD & 73 & 61 & 70 & 23 & 78 & 68 & 69 & 46 & 51 & 31 & 57 \\
\hline Skew NP & 20 & 61 & 58 & 50 & 36 & 57 & 66 & 23 & 42 & 35 & 49 \\
\hline Skewness & 19 & 39 & 8 & 20 & 34 & 59 & 28 & 11 & 14 & 25 & 26 \\
\hline Kurtosis & 51 & 44 & 5 & 77 & 56 & 67 & 67 & 24 & 63 & 84 & 54 \\
\hline
\end{tabular}

Notes: Entries are the percentage of positive values for each country and predictor variable for the individual firm regression given by equation (8). 
Table 9 - Panel Regressions: All Predictors Including Financial Crisis Dummy

\begin{tabular}{|c|c|c|c|c|c|c|c|c|c|c|c|c|}
\hline & DP & EP & CAPE & $\mathrm{DE}$ & PEG & Fed & $\mathrm{RD}$ & Max-Min & AMD & Skew NP & Skew & Kurt \\
\hline & \multicolumn{12}{|c|}{ Australia } \\
\hline$\beta$ & $\begin{array}{l}0.688^{\mathrm{b}} \\
(2.01)\end{array}$ & $\begin{array}{l}0.495^{\mathrm{b}} \\
(2.32)\end{array}$ & $\begin{array}{l}0.052^{\mathrm{a}} \\
(5.01)\end{array}$ & $\begin{array}{c}-0.005^{\mathrm{b}} \\
(1.98)\end{array}$ & $\begin{array}{l}0.002 \\
(0.51)\end{array}$ & $\begin{array}{l}0.021^{\mathrm{b}} \\
(2.05)\end{array}$ & $\begin{array}{c}0.082 \\
(0.78)\end{array}$ & $\begin{array}{l}0.002 \\
(0.21)\end{array}$ & $\begin{array}{l}0.449^{\mathrm{b}} \\
(2.49)\end{array}$ & $\begin{array}{l}-0.407^{a} \\
(-6.89)\end{array}$ & $\begin{array}{l}-0.081^{\mathrm{a}} \\
(-8.07)\end{array}$ & $\begin{array}{l}0.003 \\
(1.06)\end{array}$ \\
\hline \multirow[t]{2}{*}{$\beta * \mathrm{FC}$} & $\begin{array}{l}0.440^{\mathrm{a}} \\
(3.66)\end{array}$ & $\begin{array}{l}0.384^{\mathrm{a}} \\
(5.89)\end{array}$ & $\begin{array}{l}-0.030 \\
(-1.24) \\
\end{array}$ & $\begin{array}{l}-0.003 \\
(-0.60) \\
\end{array}$ & $\begin{array}{l}-0.001^{b} \\
(-2.38)\end{array}$ & $\begin{array}{l}0.189^{\mathrm{a}} \\
(6.42)\end{array}$ & $\begin{array}{c}4.012^{\mathrm{a}} \\
(21.77) \\
\end{array}$ & $\begin{array}{c}0.418^{\mathrm{a}} \\
(25.92)\end{array}$ & $\begin{array}{r}3.747^{\mathrm{a}} \\
(15.33)\end{array}$ & $\begin{array}{l}-1.252^{\mathrm{a}} \\
(-9.84)\end{array}$ & $\begin{array}{c}-0.867^{\mathrm{a}} \\
(-29.95) \\
\end{array}$ & $\begin{array}{l}-0.051^{b} \\
(-2.54)\end{array}$ \\
\hline & \multicolumn{12}{|c|}{ Canada } \\
\hline$\beta$ & $\begin{array}{l}0.074^{\mathrm{b}} \\
(2.28)\end{array}$ & $\begin{array}{l}0.219^{c} \\
(1.92)\end{array}$ & $\begin{array}{l}0.388^{\mathrm{a}} \\
(3.09)\end{array}$ & $\begin{array}{l}-0.005 \\
(-1.35) \\
\end{array}$ & $\begin{array}{l}0.004 \\
(0.19)\end{array}$ & $\begin{array}{l}0.079^{\mathrm{b}} \\
(2.56)\end{array}$ & $\begin{array}{l}0.418^{\mathrm{a}} \\
(5.22) \\
\end{array}$ & $\begin{array}{l}0.049^{\mathrm{a}} \\
(7.65)\end{array}$ & $\begin{array}{l}-0.049 \\
(-0.31)\end{array}$ & $\begin{array}{l}0.181^{\mathrm{a}} \\
(3.27)\end{array}$ & $\begin{array}{l}0.049^{\mathrm{a}} \\
(4.82)\end{array}$ & $\begin{array}{l}0.010^{\mathrm{a}} \\
(5.09)\end{array}$ \\
\hline \multirow[t]{2}{*}{$\beta * \mathrm{FC}$} & $\begin{array}{l}0.349^{\mathrm{a}} \\
(2.97)\end{array}$ & $\begin{array}{l}0.777^{a} \\
(3.29)\end{array}$ & $\begin{array}{l}0.826 \\
(2.44)\end{array}$ & $\begin{array}{l}0.010^{c} \\
(1.70)\end{array}$ & $\begin{array}{l}-0.001 \\
(-0.94)\end{array}$ & $\begin{array}{l}0.253^{\mathrm{a}} \\
(4.82)\end{array}$ & $\begin{array}{c}3.422^{\mathrm{a}} \\
(12.23)\end{array}$ & $\begin{array}{c}-0.828^{b} \\
(-20.65)\end{array}$ & $\begin{array}{r}5.817^{\mathrm{a}} \\
(14.81)\end{array}$ & $\begin{array}{c}-1.673^{a} \\
(-9.01)\end{array}$ & $\begin{array}{c}-0.353^{a} \\
(-15.34)\end{array}$ & $\begin{array}{l}-0.054^{a} \\
(-10.58)\end{array}$ \\
\hline & \multicolumn{12}{|c|}{ France } \\
\hline$\beta$ & $\begin{array}{l}0.063^{\mathrm{b}} \\
(2.02)\end{array}$ & $\begin{array}{l}0.072^{\mathrm{a}} \\
(2.91)\end{array}$ & $\begin{array}{l}0.062^{\mathrm{a}} \\
(3.27)\end{array}$ & $\begin{array}{l}-0.009 \\
(-0.82)\end{array}$ & $\begin{array}{l}-0.004 \\
(-1.20) \\
\end{array}$ & $\begin{array}{l}0.023^{\mathrm{a}} \\
(3.23)\end{array}$ & $\begin{array}{l}0.319 \\
(1.44) \\
\end{array}$ & $\begin{array}{l}0.038 \\
(1.04)\end{array}$ & $\begin{array}{l}-0.419 \\
(-1.18)\end{array}$ & $\begin{array}{l}-0.045 \\
(-0.65) \\
\end{array}$ & $\begin{array}{l}0.215^{\mathrm{a}} \\
(4.65)\end{array}$ & $\begin{array}{l}-0.003^{a} \\
(-3.39)\end{array}$ \\
\hline$\beta * \mathrm{FC}$ & $\begin{array}{l}0.628^{a} \\
(6.36) \\
\end{array}$ & $\begin{array}{l}0.091^{\mathrm{b}} \\
(2.23)\end{array}$ & $\begin{array}{l}0.183^{\mathrm{a}} \\
(2.79) \\
\end{array}$ & $\begin{array}{l}-0.001 \\
(-0.01) \\
\end{array}$ & $\begin{array}{l}0.004 \\
(1.28) \\
\end{array}$ & $\begin{array}{l}0.037^{\mathrm{a}} \\
(2.70) \\
\end{array}$ & $\begin{array}{r}4.319^{\mathrm{a}} \\
(6.39) \\
\end{array}$ & $\begin{array}{l}0.345^{\mathrm{c}} \\
(1.93)\end{array}$ & $\begin{array}{l}7.395^{\mathrm{a}} \\
(8.52) \\
\end{array}$ & $\begin{array}{l}0.115^{\mathrm{b}} \\
(2.15)\end{array}$ & $\begin{array}{c}-0.610^{\mathrm{a}} \\
(-10.01) \\
\end{array}$ & $\begin{array}{l}-0.157^{a} \\
(-6.85) \\
\end{array}$ \\
\hline & \multicolumn{12}{|c|}{ Germany } \\
\hline$\beta$ & $\begin{array}{l}0.106^{\mathrm{c}} \\
(1.95)\end{array}$ & $\begin{array}{l}0.055^{\mathrm{a}} \\
(2.98)\end{array}$ & $\begin{array}{l}0.027 \\
(1.16)\end{array}$ & $\begin{array}{l}-0.019^{c} \\
(-1.67)\end{array}$ & $\begin{array}{l}0.003^{\mathrm{a}} \\
(2.68)\end{array}$ & $\begin{array}{l}0.010^{c} \\
(1.84)\end{array}$ & $\begin{array}{l}-0.083 \\
(-1.28) \\
\end{array}$ & $\begin{array}{l}0.077 \\
(1.32)\end{array}$ & $\begin{array}{c}-1.507^{\mathrm{a}} \\
(4.26)\end{array}$ & $\begin{array}{l}0.255^{\mathrm{b}} \\
(2.37)\end{array}$ & $\begin{array}{l}-0.008 \\
(-0.43)\end{array}$ & $\begin{array}{l}0.005 \\
(0.55)\end{array}$ \\
\hline$\beta * \mathrm{FC}$ & $\begin{array}{l}0.612^{a} \\
(3.79)\end{array}$ & $\begin{array}{l}0.039 \\
(0.93)\end{array}$ & $\begin{array}{l}0.314^{\mathrm{a}} \\
(4.33)\end{array}$ & $\begin{array}{l}0.022 \\
(0.39)\end{array}$ & $\begin{array}{l}-0.014 \\
(-1.45)\end{array}$ & $\begin{array}{l}0.022^{c} \\
(1.87)\end{array}$ & $\begin{array}{l}1.552^{a} \\
(3.62)\end{array}$ & $\begin{array}{l}0.304^{a} \\
(3.79)\end{array}$ & $\begin{array}{l}3.236^{a} \\
(5.38)\end{array}$ & $\begin{array}{c}-0.777^{a} \\
(3.73)\end{array}$ & $\begin{array}{l}-0.451^{a} \\
(-9.53)\end{array}$ & $\begin{array}{l}0.184^{a} \\
(8.32)\end{array}$ \\
\hline & \multicolumn{12}{|c|}{ Hong Kong } \\
\hline$\beta$ & $\begin{array}{l}0.267^{\mathrm{a}} \\
(3.53)\end{array}$ & $\begin{array}{l}0.096^{\mathrm{a}} \\
(3.81)\end{array}$ & $\begin{array}{l}0.120^{\mathrm{a}} \\
(3.98)\end{array}$ & $\begin{array}{l}-0.028 \\
(-0.52) \\
\end{array}$ & $\begin{array}{l}-0.001 \\
(-1.37) \\
\end{array}$ & $\begin{array}{l}0.008^{\mathrm{b}} \\
(2.29)\end{array}$ & $\begin{array}{c}-0.063^{\mathrm{a}} \\
(-4.21) \\
\end{array}$ & $\begin{array}{l}-0.096^{a} \\
(-3.25) \\
\end{array}$ & $\begin{array}{l}-0.373 \\
(-1.46) \\
\end{array}$ & $\begin{array}{l}-0.171 \\
(-1.08) \\
\end{array}$ & $\begin{array}{l}-0.043^{b} \\
(-2.34) \\
\end{array}$ & $\begin{array}{l}0.014^{\mathrm{c}} \\
(1.88)\end{array}$ \\
\hline$\beta * \mathrm{FC}$ & $\begin{array}{l}0.365^{\mathrm{b}} \\
(2.23)\end{array}$ & $\begin{array}{l}0.131^{\mathrm{b}} \\
(2.37)\end{array}$ & $\begin{array}{l}0.478^{\mathrm{a}} \\
(5.76) \\
\end{array}$ & $\begin{array}{l}-0.186 \\
(-1.04) \\
\end{array}$ & $\begin{array}{l}-0.004^{b} \\
(-2.34) \\
\end{array}$ & $\begin{array}{l}0.032^{\mathrm{a}} \\
(4.30)\end{array}$ & $\begin{array}{l}0.011^{\mathrm{a}} \\
(8.71) \\
\end{array}$ & $\begin{array}{c}0.152^{\mathrm{a}} \\
(15.82) \\
\end{array}$ & $\begin{array}{l}8.889^{\mathrm{a}} \\
(9.61) \\
\end{array}$ & $\begin{array}{l}-0.039 \\
(-0.06) \\
\end{array}$ & $\begin{array}{c}-0.484^{\mathrm{a}} \\
(-10.49) \\
\end{array}$ & $\begin{array}{l}-0.417^{\mathrm{a}} \\
(-4.09) \\
\end{array}$ \\
\hline & \multicolumn{12}{|c|}{ Italy } \\
\hline$\beta$ & $\begin{array}{l}0.089^{\mathrm{a}} \\
(6.02)\end{array}$ & $\begin{array}{l}0.043^{\mathrm{b}} \\
(2.01)\end{array}$ & $\begin{array}{l}-0.014 \\
(-0.52) \\
\end{array}$ & $\begin{array}{l}-0.007 \\
(-0.94) \\
\end{array}$ & $\begin{array}{l}-0.001 \\
(-0.71) \\
\end{array}$ & $\begin{array}{l}0.003^{\mathrm{c}} \\
(1.87) \\
\end{array}$ & $\begin{array}{r}0.225^{\mathrm{b}} \\
(2.07) \\
\end{array}$ & $\begin{array}{l}0.003 \\
(0.49) \\
\end{array}$ & $\begin{array}{l}-1.322^{\mathrm{a}} \\
(-7.24) \\
\end{array}$ & $\begin{array}{c}-0.383^{a} \\
(-6.84) \\
\end{array}$ & $\begin{array}{c}-0.071^{\mathrm{a}} \\
(5.87) \\
\end{array}$ & $\begin{array}{l}-0.024^{\mathrm{a}} \\
(12.38)\end{array}$ \\
\hline$\beta * \mathrm{FC}$ & $\begin{array}{l}0.063^{\mathrm{b}} \\
(2.42)\end{array}$ & $\begin{array}{l}0.343^{\mathrm{a}} \\
(4.27)\end{array}$ & $\begin{array}{l}0.167^{\mathrm{b}} \\
(2.20)\end{array}$ & $\begin{array}{l}-0.005 \\
(-0.24) \\
\end{array}$ & $\begin{array}{l}0.003 \\
(0.13) \\
\end{array}$ & $\begin{array}{l}0.014^{\mathrm{a}} \\
(3.84)\end{array}$ & $\begin{array}{l}1.488^{\mathrm{a}} \\
(9.30) \\
\end{array}$ & $\begin{array}{l}0.100^{\mathrm{a}} \\
(9.49)\end{array}$ & $\begin{array}{l}4.879^{\mathrm{a}} \\
(17.32)\end{array}$ & $\begin{array}{l}0.929^{\mathrm{a}} \\
(5.38) \\
\end{array}$ & $\begin{array}{c}-0.689^{\mathrm{a}} \\
(-11.04) \\
\end{array}$ & $\begin{array}{l}0.149^{a} \\
(9.41) \\
\end{array}$ \\
\hline & \multicolumn{12}{|c|}{ Japan } \\
\hline$\beta$ & $\begin{array}{l}0.040^{\mathrm{a}} \\
(7.84)\end{array}$ & $\begin{array}{l}0.106^{\mathrm{a}} \\
(7.95)\end{array}$ & $\begin{array}{l}0.094^{\mathrm{a}} \\
(7.05)\end{array}$ & $\begin{array}{c}-0.007^{\mathrm{b}} \\
(1.97) \\
\end{array}$ & $\begin{array}{l}-0.002 \\
(-1.60) \\
\end{array}$ & $\begin{array}{l}0.011^{\mathrm{a}} \\
(8.45)\end{array}$ & $\begin{array}{l}-0.007 \\
(-0.14) \\
\end{array}$ & $\begin{array}{l}0.016^{\mathrm{a}} \\
(5.68)\end{array}$ & $\begin{array}{l}0.060 \\
(0.64) \\
\end{array}$ & $\begin{array}{l}0.459^{\mathrm{a}} \\
(6.65)\end{array}$ & $\begin{array}{l}-0.036^{a} \\
(-5.34) \\
\end{array}$ & $\begin{array}{l}-0.001 \\
(-0.08) \\
\end{array}$ \\
\hline$\beta * \mathrm{FC}$ & $0.106^{\mathrm{a}}$ & $0.101^{\mathrm{a}}$ & $0.312^{\mathrm{a}}$ & 0.006 & -0.001 & $0.013^{\mathrm{a}}$ & $2.259^{\mathrm{a}}$ & $0.289^{\mathrm{a}}$ & $2.253^{\mathrm{a}}$ & $2.708^{\mathrm{a}}$ & $-0.379^{\mathrm{a}}$ & $-0.450^{\mathrm{a}}$ \\
\hline
\end{tabular}




\begin{tabular}{|c|c|c|c|c|c|c|c|c|c|c|c|c|}
\hline & $(9.25)$ & $(4.11)$ & $(9.25)$ & $(1.60)$ & $(-0.13)$ & $(4.74)$ & $(12.13)$ & $(8.34)$ & $(11.09)$ & $(3.41)$ & $(-13.77)$ & $(-13.55)$ \\
\hline & \multicolumn{12}{|c|}{ South Korea } \\
\hline$\beta$ & $\begin{array}{l}0.033^{\mathrm{a}} \\
(8.85)\end{array}$ & $\begin{array}{l}0.006 \\
(1.62)\end{array}$ & $\begin{array}{l}0.017 \\
(1.02)\end{array}$ & $\begin{array}{l}0.010^{\mathrm{b}} \\
(2.18)\end{array}$ & $\begin{array}{l}0.001^{\mathrm{a}} \\
(2.64)\end{array}$ & $\begin{array}{l}0.016 \\
(1.34)\end{array}$ & $\begin{array}{c}-0.190^{c} \\
(-1.79)\end{array}$ & $\begin{array}{l}-0.059^{a} \\
(-3.99)\end{array}$ & $\begin{array}{l}-0.063 \\
(-0.45)\end{array}$ & $\begin{array}{l}-1.350^{\mathrm{a}} \\
(-10.98)\end{array}$ & $\begin{array}{c}-0.365^{a} \\
(-18.28)\end{array}$ & $\begin{array}{c}-0.034 \mathrm{a} \\
(-7.42)\end{array}$ \\
\hline \multirow[t]{2}{*}{$\beta * \mathrm{FC}$} & $\begin{array}{l}-0.009 \\
(-0.87)\end{array}$ & $\begin{array}{l}0.161^{a} \\
(6.63)\end{array}$ & $\begin{array}{l}0.091^{\mathrm{a}} \\
(4.21)\end{array}$ & $\begin{array}{l}0.031 \\
(1.55)\end{array}$ & $\begin{array}{l}0.013 \\
(0.98)\end{array}$ & $\begin{array}{l}0.838^{a} \\
(6.84)\end{array}$ & $\begin{array}{c}-4.642^{a} \\
(-9.70)\end{array}$ & $\begin{array}{l}0.148^{c} \\
(1.82)\end{array}$ & $\begin{array}{c}-4.757^{a} \\
(-10.76)\end{array}$ & $\begin{array}{l}-3.212^{\mathrm{a}} \\
(-8.65)\end{array}$ & $\begin{array}{c}-0.837^{a} \\
(-10.16)\end{array}$ & $\begin{array}{l}-0.003 \\
(-0.11)\end{array}$ \\
\hline & \multicolumn{12}{|c|}{ UK } \\
\hline$\beta$ & $\begin{array}{l}0.168^{\mathrm{a}} \\
(4.99)\end{array}$ & $\begin{array}{l}0.152^{\mathrm{a}} \\
(3.91)\end{array}$ & $\begin{array}{l}0.074^{\mathrm{a}} \\
(3.52)\end{array}$ & $\begin{array}{l}-0.001 \\
(-0.65)\end{array}$ & $\begin{array}{l}0.001 \\
(0.55)\end{array}$ & $\begin{array}{l}0.008^{\mathrm{a}} \\
(7.65)\end{array}$ & $\begin{array}{l}0.404^{\mathrm{a}} \\
(7.11)\end{array}$ & $\begin{array}{l}0.014^{\mathrm{b}} \\
(2.57)\end{array}$ & $\begin{array}{l}0.381^{\mathrm{a}} \\
(3.23)\end{array}$ & $\begin{array}{l}0.277^{\mathrm{a}} \\
(6.05)\end{array}$ & $\begin{array}{c}-0.095^{a} \\
(-16.08)\end{array}$ & $\begin{array}{l}0.002 \\
(1.35)\end{array}$ \\
\hline$\beta * \mathrm{FC}$ & $\begin{array}{l}0.059^{\mathrm{a}} \\
(3.47)\end{array}$ & $\begin{array}{l}0.179^{\mathrm{a}} \\
(3.52)\end{array}$ & $\begin{array}{l}0.272^{\mathrm{a}} \\
(6.53)\end{array}$ & $\begin{array}{l}0.050^{\mathrm{b}} \\
(2.16)\end{array}$ & $\begin{array}{l}0.001^{\mathrm{b}} \\
(2.35)\end{array}$ & $\begin{array}{l}0.027^{c} \\
(1.83)\end{array}$ & $\begin{array}{c}1.574^{\mathrm{a}} \\
(17.28)\end{array}$ & $\begin{array}{l}0.458^{\mathrm{a}} \\
(3.85)\end{array}$ & $\begin{array}{l}2.171^{\mathrm{a}} \\
(9.77)\end{array}$ & $\begin{array}{c}-0.340^{\mathrm{a}} \\
(3.85)\end{array}$ & $\begin{array}{l}-0.392^{\mathrm{a}} \\
(-8.35)\end{array}$ & $\begin{array}{l}0.058^{\mathrm{a}} \\
(4.38)\end{array}$ \\
\hline & \multicolumn{12}{|c|}{ US } \\
\hline$\beta$ & $\begin{array}{l}0.019^{c} \\
(1.75)\end{array}$ & $\begin{array}{l}0.055^{\mathrm{a}} \\
(5.47)\end{array}$ & $\begin{array}{l}0.052^{\mathrm{a}} \\
(6.80)\end{array}$ & $\begin{array}{c}-0.004^{\mathrm{b}} \\
(1.98)\end{array}$ & $\begin{array}{l}-0.001 \\
(-0.74)\end{array}$ & $\begin{array}{l}0.012^{\mathrm{a}} \\
(7.01)\end{array}$ & $\begin{array}{l}0.099^{\mathrm{b}} \\
(2.41)\end{array}$ & $\begin{array}{l}0.001 \\
(0.17)\end{array}$ & $\begin{array}{l}0.008 \\
(0.89)\end{array}$ & $\begin{array}{l}0.014^{\mathrm{b}} \\
(2.49)\end{array}$ & $\begin{array}{l}-0.009 \\
(-1.54)\end{array}$ & $\begin{array}{l}0.004 \\
(1.54)\end{array}$ \\
\hline$\beta * \mathrm{FC}$ & $\begin{array}{l}0.143^{\mathrm{a}} \\
(5.14)\end{array}$ & $\begin{array}{l}0.011 \\
(0.91)\end{array}$ & $\begin{array}{l}0.031^{b} \\
(2.52)\end{array}$ & $\begin{array}{l}0.003 \\
(1.10)\end{array}$ & $\begin{array}{l}0.001^{\mathrm{a}} \\
(3.34)\end{array}$ & $\begin{array}{l}0.015^{\mathrm{a}} \\
(3.69)\end{array}$ & $\begin{array}{l}0.089 \\
(0.86)\end{array}$ & $\begin{array}{l}-0.090^{\mathrm{a}} \\
(-9.77)\end{array}$ & $\begin{array}{l}0.090 \\
(0.44)\end{array}$ & $\begin{array}{l}-0.186^{\mathrm{a}} \\
(-8.02)\end{array}$ & $\begin{array}{c}-0.362^{\mathrm{a}} \\
(-28.53)\end{array}$ & $\begin{array}{c}0.247^{\mathrm{a}} \\
(18.35)\end{array}$ \\
\hline
\end{tabular}

Notes: the entries are the coefficient values (and $t$-statistics) from the panel regression of equation (1) using the cross-section adjusted forward recursively demeaned (RDAdj) approach. In addition, we include a dummy variable for the financial crisis (FC, 2007-2009). The superscript letters a, b, c refer to 1\%, 5\%, and 10\% statistical significance level respectively. 
Table 10. Time-Variation - Percentage of Positive Values

\begin{tabular}{|c|c|c|c|c|c|c|c|c|c|c|c|}
\hline & Aus & Can & Fra & Ger & $\mathrm{HK}$ & Ity & Jpy & SK & UK & US & Ave \\
\hline DP & 65 & 55 & 60 & 80 & 70 & 65 & 70 & 60 & 60 & 55 & 64 \\
\hline EP & 65 & 50 & 75 & 55 & 70 & 60 & 65 & 65 & 60 & 65 & 63 \\
\hline CAPE & 70 & 70 & 65 & 70 & 65 & 60 & 65 & 60 & 55 & 70 & 65 \\
\hline $\mathrm{DE}$ & 75 & 65 & 55 & 65 & 55 & 100 & 55 & 50 & 55 & 35 & 61 \\
\hline PEG & 80 & 50 & 53 & 47 & 26 & 58 & 50 & 70 & 55 & 60 & 55 \\
\hline Fed & 65 & 50 & 75 & 55 & 60 & 60 & 65 & 55 & 55 & 65 & 61 \\
\hline DISP & 61 & 78 & 72 & 61 & 50 & 72 & 44 & 33 & 56 & 56 & 58 \\
\hline Ma-Mi & 61 & 67 & 56 & 61 & 44 & 61 & 56 & 50 & 67 & 44 & 57 \\
\hline AMD & 56 & 56 & 78 & 44 & 72 & 61 & 44 & 39 & 44 & 61 & 56 \\
\hline Skew NP & 39 & 44 & 50 & 50 & 39 & 33 & 44 & 17 & 44 & 44 & 40 \\
\hline Skewness & 39 & 61 & 44 & 39 & 50 & 39 & 39 & 33 & 39 & 61 & 44 \\
\hline Kurtosis & 67 & 67 & 39 & 61 & 44 & 33 & 50 & 44 & 67 & 50 & 52 \\
\hline
\end{tabular}

Notes: Entries are the percentage of positive values for each country and predictor variable for the time-varying regression given by equation (9). 
Table 11. GDP and Predictive Coefficients

\begin{tabular}{|c|c|c|c|c|c|c|c|c|c|c|}
\hline Pred & AUS & CAN & FRA & GER & HK & ITY & JP & SK & UK & US \\
\hline$\overline{\mathrm{DP}}$ & $\begin{array}{l}0.431^{\mathrm{a}} \\
(3.56)\end{array}$ & $\begin{array}{l}0.396 \\
(1.56)\end{array}$ & $\begin{array}{c}0.143^{\mathrm{a}} \\
(7.11)\end{array}$ & $\begin{array}{l}0.159^{\mathrm{a}} \\
(4.01)\end{array}$ & $\begin{array}{l}0.214^{\mathrm{a}} \\
(4.09)\end{array}$ & $\begin{array}{c}0.306^{\mathrm{a}} \\
(5.58)\end{array}$ & $\begin{array}{c}0.089^{\mathrm{b}} \\
(2.51)\end{array}$ & $\begin{array}{l}0.165 \\
(1.52)\end{array}$ & $\begin{array}{c}0.249^{\mathrm{a}} \\
(3.50)\end{array}$ & $\begin{array}{c}0.133^{\mathrm{b}} \\
(2.50)\end{array}$ \\
\hline EP & $\begin{array}{l}0.665^{\mathrm{a}} \\
(8.74)\end{array}$ & $\begin{array}{l}0.567 \\
(1.54) \\
\end{array}$ & $\begin{array}{l}0.445^{\mathrm{a}} \\
(5.67)\end{array}$ & $\begin{array}{l}0.487^{\mathrm{a}} \\
(3.68) \\
\end{array}$ & $\begin{array}{l}0.550^{\mathrm{a}} \\
(4.22)\end{array}$ & $\begin{array}{l}0.766^{\mathrm{a}} \\
(2.97)\end{array}$ & $\begin{array}{c}0.306 \mathrm{~b} \\
(2.24)\end{array}$ & $\begin{array}{l}0.831^{\mathrm{b}} \\
(2.08)\end{array}$ & $\begin{array}{l}0.383 \\
(1.63) \\
\end{array}$ & $\begin{array}{l}0.291^{\mathrm{c}} \\
(1.80)\end{array}$ \\
\hline CAPE & $\begin{array}{l}0.367^{\mathrm{a}} \\
(8.97)\end{array}$ & $\begin{array}{l}0.457^{\mathrm{a}} \\
(3.95)\end{array}$ & $\begin{array}{l}0.282^{\mathrm{a}} \\
(6.56)\end{array}$ & $\begin{array}{l}0.326^{\mathrm{a}} \\
(3.94)\end{array}$ & $\begin{array}{l}0.381^{\mathrm{a}} \\
(3.20)\end{array}$ & $\begin{array}{l}0.573^{\mathrm{a}} \\
(9.72)\end{array}$ & $\begin{array}{l}0.236^{\mathrm{a}} \\
(2.58)\end{array}$ & $\begin{array}{l}0.943^{c} \\
(1.89)\end{array}$ & $\begin{array}{l}0.520^{\mathrm{a}} \\
(6.40)\end{array}$ & $\begin{array}{l}0.277^{\mathrm{b}} \\
(2.45)\end{array}$ \\
\hline $\mathrm{DE}$ & $\begin{array}{l}0.109^{\mathrm{a}} \\
(3.53)\end{array}$ & $\begin{array}{l}0.596 \\
(1.38)\end{array}$ & $\begin{array}{l}0.274^{\mathrm{a}} \\
(7.87)\end{array}$ & $\begin{array}{l}0.339^{\mathrm{a}} \\
(8.00)\end{array}$ & $\begin{array}{l}0.398^{\mathrm{a}} \\
(4.19)\end{array}$ & $\begin{array}{l}-0.286 \\
(-0.98)\end{array}$ & $\begin{array}{l}0.267 \\
(1.51)\end{array}$ & $\begin{array}{l}0.233^{c} \\
(1.85)\end{array}$ & $\begin{array}{l}0.463^{\mathrm{b}} \\
(2.35)\end{array}$ & $\begin{array}{l}0.589^{c} \\
(1.87)\end{array}$ \\
\hline PEG & $\begin{array}{l}0.640 \\
(0.72) \\
\end{array}$ & $\begin{array}{l}0.236 \\
(1.57) \\
\end{array}$ & $\begin{array}{l}-0.276 \\
(-0.66) \\
\end{array}$ & $\begin{array}{l}0.164^{c} \\
(1.81)\end{array}$ & $\begin{array}{l}0.169 \\
(0.49) \\
\end{array}$ & $\begin{array}{l}0.382^{a} \\
(6.76)\end{array}$ & $\begin{array}{l}0.592^{\mathrm{a}} \\
(2.92)\end{array}$ & $\begin{array}{l}-0.474 \\
(-1.09) \\
\end{array}$ & $\begin{array}{l}0.980 \\
(1.32) \\
\end{array}$ & $\begin{array}{l}0.165 \\
(0.92) \\
\end{array}$ \\
\hline Fed & $\begin{array}{l}0.113^{\mathrm{a}} \\
(9.94)\end{array}$ & $\begin{array}{l}0.102 \\
(1.09)\end{array}$ & $\begin{array}{l}0.102^{\mathrm{a}} \\
(6.47)\end{array}$ & $\begin{array}{l}0.099^{\mathrm{a}} \\
(2.78)\end{array}$ & $\begin{array}{l}0.139^{\mathrm{a}} \\
(4.16)\end{array}$ & $\begin{array}{l}0.110^{\mathrm{c}} \\
(1.91)\end{array}$ & $\begin{array}{l}0.153^{\mathrm{b}} \\
(2.19)\end{array}$ & $\begin{array}{l}0.477^{c} \\
(1.65)\end{array}$ & $\begin{array}{l}0.105^{\mathrm{c}} \\
(1.70)\end{array}$ & $\begin{array}{l}0.061^{\mathrm{c}} \\
(1.80)\end{array}$ \\
\hline $\mathrm{RD}$ & $\begin{array}{l}-0.054^{b} \\
(-2.51)\end{array}$ & $\begin{array}{l}0.111 \\
(1.39)\end{array}$ & $\begin{array}{c}-0.67 \\
(-0.93) \\
\end{array}$ & $\begin{array}{l}-0.016 \\
(-0.05) \\
\end{array}$ & $\begin{array}{l}0.138 \\
(0.96)\end{array}$ & $\begin{array}{l}0.075^{c} \\
(1.74)\end{array}$ & $\begin{array}{l}-0.098 \\
(-0.93) \\
\end{array}$ & $\begin{array}{l}0.002 \\
(1.56)\end{array}$ & $\begin{array}{l}0.241^{\mathrm{b}} \\
(2.20)\end{array}$ & $\begin{array}{l}-0.090 \\
(1.05)\end{array}$ \\
\hline Ma-Mi & $\begin{array}{l}0.062 \\
(0.49) \\
\end{array}$ & $\begin{array}{l}0.037^{\mathrm{b}} \\
(2.03)\end{array}$ & $\begin{array}{l}0.283^{c} \\
(1.95)\end{array}$ & $\begin{array}{l}0.134 \\
(0.61) \\
\end{array}$ & $\begin{array}{l}-0.243 \\
(-0.89) \\
\end{array}$ & $\begin{array}{l}-0.001 \\
(-0.23) \\
\end{array}$ & $\begin{array}{l}-0.290 \\
(-0.72) \\
\end{array}$ & $\begin{array}{l}-0.003 \\
(-0.68) \\
\end{array}$ & $\begin{array}{l}-0.144 \\
(-0.25) \\
\end{array}$ & $\begin{array}{l}0.017 \\
(0.73) \\
\end{array}$ \\
\hline AMD & $\begin{array}{l}0.64^{\mathrm{a}} \\
(4.55) \\
\end{array}$ & $\begin{array}{l}-0.037^{\mathrm{c}} \\
(-1.67) \\
\end{array}$ & $\begin{array}{l}-0.028 \\
(-1.64) \\
\end{array}$ & $\begin{array}{l}0.054 \\
(0.67) \\
\end{array}$ & $\begin{array}{l}0.018 \\
(0.73) \\
\end{array}$ & $\begin{array}{l}-0.005 \\
(-0.26) \\
\end{array}$ & $\begin{array}{l}0.060 \\
(1.28) \\
\end{array}$ & $\begin{array}{l}0.030 \\
(0.38) \\
\end{array}$ & $\begin{array}{l}0.032^{\mathrm{a}} \\
(3.10)\end{array}$ & $\begin{array}{l}0.004 \\
(0.26) \\
\end{array}$ \\
\hline Skew NP & $\begin{array}{l}0.031^{\mathrm{a}} \\
(3.28)\end{array}$ & $\begin{array}{l}0.104^{\mathrm{a}} \\
(2.71)\end{array}$ & $\begin{array}{l}0.002 \\
(0.16)\end{array}$ & $\begin{array}{l}-0.152 \\
(-0.88) \\
\end{array}$ & $\begin{array}{l}-0.227^{\mathrm{a}} \\
(-5.42)\end{array}$ & $\begin{array}{l}-0.078 \\
(-0.69) \\
\end{array}$ & $\begin{array}{l}0.117^{a} \\
(2.78)\end{array}$ & $\begin{array}{l}0.072 \\
(0.82)\end{array}$ & $\begin{array}{l}0.124^{c} \\
(1.84)\end{array}$ & $\begin{array}{l}-0.116 \\
(-0.88)\end{array}$ \\
\hline Skewness & $\begin{array}{l}0.096^{\mathrm{a}} \\
(3.92) \\
\end{array}$ & $\begin{array}{l}-0.428^{c} \\
(-1.88) \\
\end{array}$ & $\begin{array}{l}0.058 \\
(0.44) \\
\end{array}$ & $\begin{array}{l}-0.067 \\
(-0.63) \\
\end{array}$ & $\begin{array}{l}0.158 \\
(1.33)\end{array}$ & $\begin{array}{l}0.105^{\mathrm{a}} \\
(2.71)\end{array}$ & $\begin{array}{l}0.320^{\mathrm{c}} \\
(1.88)\end{array}$ & $\begin{array}{l}-0.128 \\
(-1.38) \\
\end{array}$ & $\begin{array}{l}0.223^{\mathrm{c}} \\
(1.80)\end{array}$ & $\begin{array}{l}0.031 \\
(0.19)\end{array}$ \\
\hline Kurtosis & $\begin{array}{c}-0.150^{\mathrm{a}} \\
(-3.12)\end{array}$ & $\begin{array}{l}-1.037 \\
(-1.38)\end{array}$ & $\begin{array}{l}0.965 \\
(0.87)\end{array}$ & $\begin{array}{c}0.038 \\
(0.55)\end{array}$ & $\begin{array}{l}0.518^{\mathrm{a}} \\
(6.10)\end{array}$ & $\begin{array}{l}0.654^{\mathrm{a}} \\
(6.23)\end{array}$ & $\begin{array}{l}0.112^{\mathrm{a}} \\
(5.71)\end{array}$ & $\begin{array}{l}-0.016 \\
(-0.78)\end{array}$ & $\begin{array}{l}0.884 \\
(0.73)\end{array}$ & $\begin{array}{l}-0.795^{\mathrm{c}} \\
(-1.88)\end{array}$ \\
\hline
\end{tabular}


Figure 1. Individual Firm Coefficients for Stock Returns Regressed against EP Ratio - UK

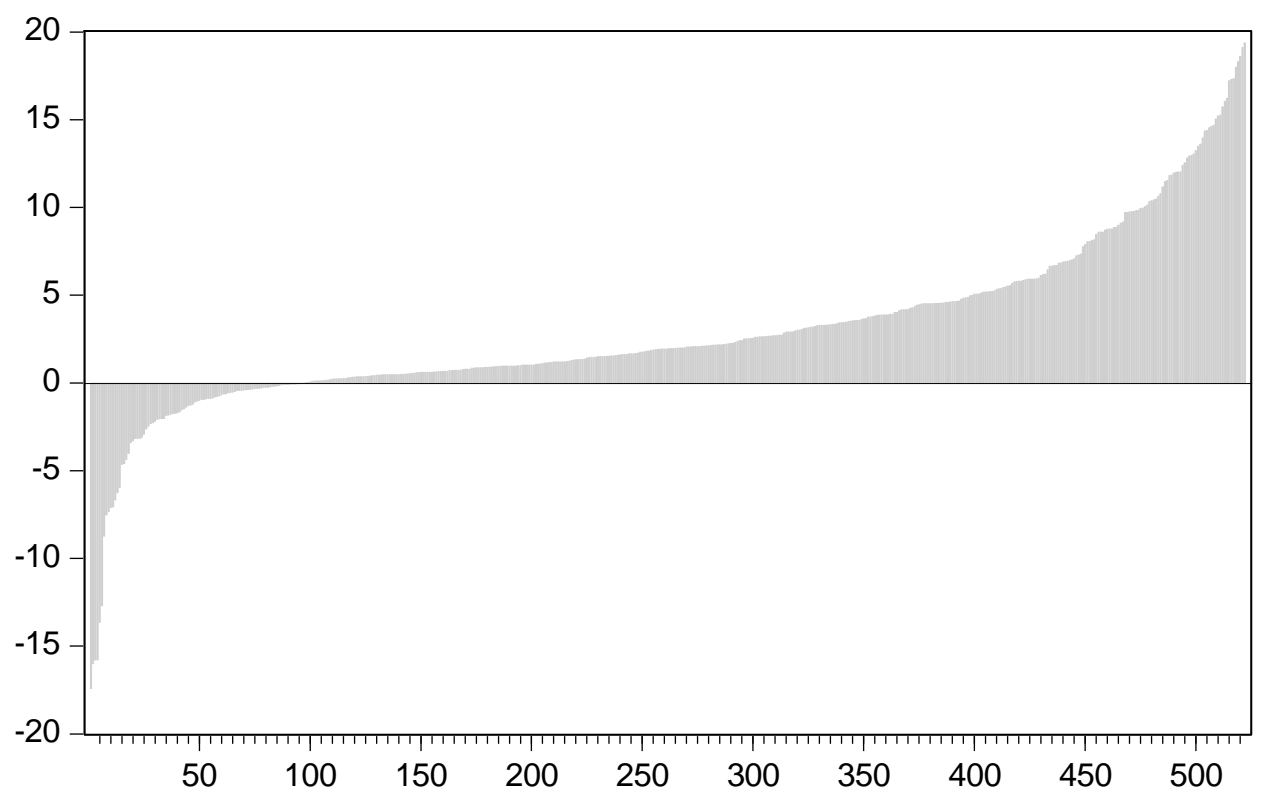

This figure shows the coefficient values obtained from equation (2) across all UK firms for the EP predictor variable 
Figure 2. Time-Varying Coefficient for Stock Returns Regressed against EP Ratio - UK

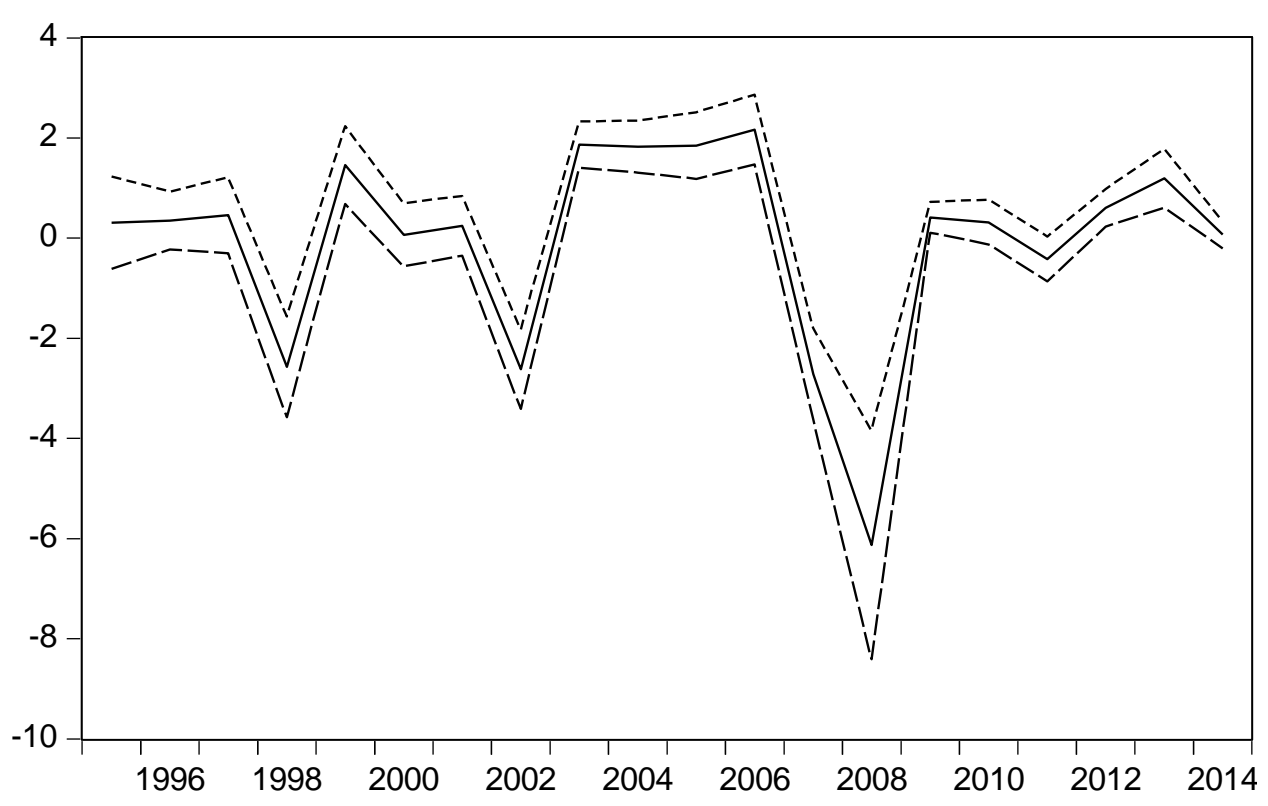

This figure shows the coefficient values (with two times the standard error bands) obtained from equation (3) across time-periods for UK firms for the EP predictor variable 